NBER WORKING PAPER SERIES

\title{
THE DECISION TO DELAY SOCIAL SECURITY BENEFITS: THEORY AND EVIDENCE
}

\author{
John B. Shoven \\ Sita Nataraj Slavov \\ Working Paper 17866 \\ http://www.nber.org/papers/w17866 \\ NATIONAL BUREAU OF ECONOMIC RESEARCH \\ 1050 Massachusetts Avenue \\ Cambridge, MA 02138 \\ February 2012
}

This research was supported by the U.S. Social Security Administration through grant \#5RRC08098400-04-00 to the National Bureau of Economic Research (NBER) as part of the SSA Retirement Research Consortium. The findings and conclusions expressed are solely those of the authors and do not represent the views of SSA, any agency of the Federal Government, or the NBER. The authors are grateful to Phoebe Yu for outstanding research assistance; to Jason Scott and David Weaver for helpful discussion and comment; and to Steve Goss, Michael Morris, and Alice Wade for providing the SSA's cohort life tables used in this paper. The first author is a member of the board of directors of Financial Engines, a Nasdaq-listed company which assists individuals with retirement planning. Financial Engines provided no financial support for this research. The authors are doing related research that is supported by the Alfred P. Sloan Foundation. The views and approaches in this paper are solely those of the authors.

NBER working papers are circulated for discussion and comment purposes. They have not been peerreviewed or been subject to the review by the NBER Board of Directors that accompanies official NBER publications.

(C) 2012 by John B. Shoven and Sita Nataraj Slavov. All rights reserved. Short sections of text, not to exceed two paragraphs, may be quoted without explicit permission provided that full credit, including (c) notice, is given to the source. 
The Decision to Delay Social Security Benefits: Theory and Evidence

John B. Shoven and Sita Nataraj Slavov

NBER Working Paper No. 17866

February 2012

JEL No. D14,H55

\begin{abstract}
$\underline{\text { ABSTRACT }}$
Social Security benefits may be commenced at any time between age 62 and age 70 . As individuals who claim later can, on average, expect to receive benefits for a shorter period, an actuarial adjustment is made to the monthly benefit amount to reflect the age at which benefits are claimed. We investigate the actuarial fairness of this adjustment. Our simulations suggest that delaying is actuarially advantageous for a large subset of people, particularly for real interest rates of 3.5 percent or below. The gains from delaying are greater at lower interest rates, for married couples relative to singles, for single women relative to single men, and for two-earner couples relative to one-earner couples. In a two-earner couple, the gains from deferring the primary earner's benefit are greater than the gains from deferring the secondary earner's benefit. We then use panel data from the Health and Retirement Study to investigate whether individuals' actual claiming behavior appears to be influenced by the degree of actuarial advantage to delaying. We find no evidence of a consistent relationship between claiming behavior and factors that influence the actuarial advantage of delay, including gender and marital status, interest rates, subjective discount rates, or subjective assessments of life expectancy.
\end{abstract}

\author{
John B. Shoven \\ Department of Economics \\ 579 Serra Mall at Galvez Street \\ Stanford, CA 94305-6015 \\ and NBER \\ shoven@stanford.edu \\ Sita Nataraj Slavov \\ Department of Economics \\ Occidental College \\ 1600 Campus Road \\ Los Angeles, CA 90041 \\ and NBER \\ sslavov@oxy.edu
}




\section{Introduction}

Upon reaching the age of 62 , individuals face an important question: what is the right time to begin collecting Social Security benefits? Social Security benefits may be commenced at any time between age 62 and age 70, with a "full" retirement benefit payable at the full retirement age (66 for individuals reaching age 62 in 2012). ${ }^{1}$ As individuals who claim later can, on average, expect to receive benefits for a shorter period, an actuarial adjustment is made to the monthly benefit amount to reflect the age at which benefits are claimed. Claiming at age 62 results in a monthly benefit that is 75 percent of the benefit that could be claimed at age 66 . On the other hand, delaying until age 70 results in a benefit that is 32 percent higher than the benefit that could be claimed at age 66 . Thus, the real monthly benefit is 76 percent greater if one waits until 70 rather than starting benefits at 62 . Delaying Social Security is equivalent to purchasing a real annuity. Individuals who delay forgo benefits in the current year in exchange for a higher monthly benefit for the rest of their lives.

It is widely believed the benefit adjustments made for delaying Social Security benefits are actuarially fair. In other words, the average individual receives the same expected present value regardless of when benefits begin. Of course, even if the adjustments were actuarially fair for the population on average, they would not be actuarially fair for every individual. For example, those who expect to live longer than average can benefit from delaying, while those who expect to live shorter than average can benefit from claiming early. In addition, the spousal and survivor benefits offered by Social Security make delaying benefits a particularly attractive option for married couples. One member of a two-earner married couple may claim spousal

\footnotetext{
${ }^{1}$ Strictly speaking, individuals who continue to work beyond age 62 may not have full flexibility to claim at any time between ages 62 and 70. In particular, claiming before full retirement age may be limited by the earnings test, which reduces benefits for wages received above a certain threshold. The earnings test effectively forces delay. Any months of benefits forgone due to the earnings test are treated as months of delay and increase benefits paid at full retirement age.
} 
benefits upon reaching full retirement age, leaving the benefit based on his or her own earnings record to accumulate through deferral. The secondary earner in a couple also receives a survivor benefit that is equal to the primary earner's benefit. Thus, delaying the primary earner's benefit is equivalent to purchasing a second-to-die or joint life annuity. In contrast, a single person ${ }^{2}$ who delays claiming only receives a single life annuity based on his or her own earnings record.

Moreover, actuarial fairness for the population on average depends on a number of other factors that vary through time. First of all, it depends crucially on interest rates: lower interest rates raise the present value of the gains from delaying benefits. Indeed, private firms that sell annuities continually vary the amount of the annuity payments they offer as interest rates change. Second, it depends on average life expectancy: improvements in life expectancy raise the gains from delaying benefits. Again, the terms of private annuities have become less generous in response to gains in life expectancy over the past few decades. In contrast, aside from a modest increase in the full retirement age, the terms for delaying Social Security up to full retirement age have been largely unchanged since 1956 for women and 1961 for men. ${ }^{3}$ The terms for delaying beyond full retirement age have become more generous over the years: members of the 1924 birth cohort could earn 3 percent of their base benefit per year of delay beyond full retirement age, while members of cohorts born in 1943 and later can earn 8 percent of their base benefit per year of delay beyond full retirement age. ${ }^{4}$

\footnotetext{
${ }^{2}$ This comment refers to a never-married single person. A divorced single person whose marriage lasted at least 10 years may claim spousal and survivor benefits on the ex-spouse's record.

${ }^{3}$ It is not obvious whether the increase in full retirement age - from 65 to 66 - has by itself made delays more or less advantageous. Delaying from 62 to 65 results in a 25 percent gain when the full retirement age is 65 , and a 24.4 percent gain when the full retirement age is 66 . However, delaying from 63 to 65 results in a 15.4 percent gain when the full retirement age is 65 , and a 16.7 percent gain when the full retirement age is 66 . For claims made before full retirement age, Jivan (2004) argues that the improvements in life expectancy between 1960 and 2004 have been offset by increases in the real interest rate, leaving the gain from delays roughly constant.

${ }^{4}$ For more details, see http://www.ssa.gov/oact/ProgData/ar_drc.html.
} 
In this paper, we investigate the conditions under which delaying Social Security may be actuarially advantageous. We simulate Social Security benefits for variety of cases (singles as well as married couples with varying levels of income) and find the claiming strategies that maximize the expected present value of benefits. Our simulations suggest that delaying is actuarially advantageous for a large subset of people. The gains from delaying are greater at lower interest rates, for married couples relative to singles, for single women relative to single men, and (at most interest rates) for two-earner couples relative to one-earner couples. In addition, within a married couple, the gains from deferring the primary earner's benefit are greater than the gains from deferring the secondary earner's benefit. We find that at relatively low interest rates (similar to those that prevail today), primary earners with average life expectancy should delay benefits to age 70 to maximize expected present value. Singles with average life expectancy should delay beyond their full retirement age as well.

After identifying the factors that make delaying actuarially advantageous, we use panel data from the Health and Retirement Study (HRS) to investigate whether individuals' actual claiming behavior appears to be influenced by the degree of actuarial advantage to delaying. We find no evidence of a consistent relationship between claiming behavior and the factors that influence the expected present value of benefits, including gender and marital status, interest rates, health status, and subjective assessments of life expectancy. Indeed, among individuals who stopped working before age 62 , more than 75 percent claim within two months of reaching 62 . Similarly, among individuals who were not working at the time of their claim, more than 75 percent claim within two months of the later of stopping work or reaching 62 . The only factors that are consistently related to delayed claiming are labor force status (individuals who work longer tend 
to delay their claims) and college education (individuals who have attended college are more likely to delay their claims).

The remainder of this paper is organized as follows. Section 2 reviews the relevant literature, Section 3 presents our simulation methodology and results, Section 4 presents our empirical analysis, and Section 5 concludes.

\section{Literature}

A few authors have done calculations investigating the actuarial fairness of the adjustment made for delays, and characterizing present-value maximizing claiming strategies (Meyer and Reichenstein 2010; Munnell and Soto 2005; Sass, Sun, and Webb 2007; Coile et al. 2002; Jivan 2004). A general finding is that delays are actuarially advantageous for primary earners, using real discount/interest rates of 2-3 percent. However, the gains from delay are small at best for singles, particularly for single men. Sass, Sun, and Webb (2008) demonstrate that while delays by the primary earner boost the total present value of household Social Security benefits, they have an even greater impact on the benefits received by a widowed secondary earner, whose survivor benefit depends on the actual amount of the primary earner's benefit (including credits for delay). Shuart, Weaver, and Whitman (2010) investigate optimal claiming strategies for widow benefits, either alone or in combination with worker benefits. They find that it is often optimal to claim one benefit first and allow the other to grow through delay.

A related strand of literature examines actual claiming decisions. Using data on individuals retiring in the early 1980s, Coile et al. (2002) show that longer delays are related to the factors that underlie actuarial advantage, including a longer (realized) life expectancy and a younger spouse. However, they note that a large number of individuals claim at age 62 , which is 
inconsistent with the general prediction of their model that delays are often actuarially advantageous. Using data from the Health and Retirement Study (HRS), Munnell and Soto (2005) document that married women are most likely to claim early, followed by single men, married men, and single women. This is consistent with their claim that while single women benefit from delay through longer life expectancy, secondary earners (typically wives) generally do not benefit from delay. However, other studies find little relationship between actuarial advantage and claiming. Hurd, Smith, and Zissimopoulos (2004) use HRS data from 1992-1998 to demonstrate that subjective assessments of mortality risk are associated with early retirement and early claiming, though the effect is small. They find no relationship between wealth and claiming, although stock ownership (which they argue proxies for a higher rate of return on investment) is associated with early claiming. Sass, Sun, and Webb (2007) also use HRS data (from 1998-2003) and find little evidence of a relationship between a husband's decision to delay claiming to age 63 or later, and a number of factors that are related to the benefit from claiming, including wealth, subjective life expectancy, financial planning horizon, and financial literacy. They do, however, find a positive relationship between college education and delayed claiming. Again, both of these HRS-based studies document that the majority of individuals claim immediately after turning 62. Liebman and Luttmer (2011) describe a field experiment in which individuals received an informational brochure about how Social Security benefits are calculated, including a description of the increases for delaying benefits. They demonstrate that the treatment delayed retirement decisions, but did not have a significant impact on claiming decisions. In another experimental setting, Brown, Kapteyn, and Mitchell (2011) show that individuals' self reports of their intended claiming age depends on the way in which the claiming decision is framed. 
As delaying Social Security is equivalent to buying an annuity, this paper is also related to the extensive literature on the demand for annuities. A recurring theme in this literature is the fact that most people do not convert their retirement savings into annuities, even though annuities would appear to increase their utility by insuring them against outliving their savings (e.g., Yaari 1965; Mitchell et al. 1999; Bütler and Teppa 2007; Brown, Casey, and Mitchell 2007). There are a number of explanations for limited annuity demand, such as adverse selection, large administrative costs, bequest motives, cognitive bias, or lack of financial knowledge; Brown $(2007 ; 2008)$ provides a survey. Because delaying Social Security is equivalent to buying an annuity, the failure to delay Social Security when it is actuarially advantageous may be a different aspect of the same puzzle. A related point is that if delaying Social Security is actuarially advantageous relative to private annuities, we should expect individuals to delay Social Security as much as possible before buying private annuities. In other words, buying a private annuity without delaying Social Security is suboptimal.

The contribution of our paper is to provide a more detailed analysis of the actuarial advantage from delay. In particular, we pay greater attention to the role of the real discount rate, computing optimal claiming strategies for a wide range of rates. This is particularly important in light of today's near-zero real interest rates, which make private annuities less attractive relative to delaying claiming and financing the delay out of private saving. We also do a detailed analysis of claiming strategies for two-earner couples, paying particular attention to the optimal use of spousal and widow benefits. Our empirical analysis - using HRS data - provides an update to that of Hurd, Smith, and Zissimopoulos (2004) and Sass, Sun, and Webb (2007). With additional waves of HRS data, we are able to collect a large sample of individuals who are observed consistently between ages 62 and 70 . 


\section{Simulations}

\section{a. Methodology}

An individual's Social Security benefit is based on his or her Average Indexed Monthly Earnings (AIME), which is defined as the average monthly income computed over the highest 35 years of covered earnings. In performing this calculation, wages earned prior to age 60 are indexed for average wage growth in the economy. A progressive benefit formula is then applied to the AIME to derive the Primary Insurance Amount (PIA), which is the monthly benefit payable at full retirement age. For individuals in the 1950 birth cohort (with a full retirement age of 66), PIA is equal to 90 percent of the first $\$ 767$ of AIME, 32 percent of the next $\$ 3,857$ of AIME, and 15 percent of the remaining AIME. Claiming up to 36 months before full retirement age results in a benefit reduction of $5 / 9$ of one percent of PIA for each month. Beyond 36 months, benefits are reduced by 5/12 of one percent of PIA per month. For individuals reaching full retirement age in 2009 or later, delaying retirement beyond full retirement age results in a benefit increase of $2 / 3$ of one percent of PIA per month (or 8 percent of PIA per year). Benefits may be claimed as early as age 62 or delayed until age 70 . Regardless of claiming age, PIA is indexed for inflation starting at age 62, and benefits are paid as a life annuity (i.e., they continue and are constant in real terms until death). All of our calculations in this paper are done in real terms, using 2012 dollars.

A married person may claim benefits on his or her own record (worker benefit), but may also claim a benefit on his or her spouse's record (spousal benefit). If both benefits are claimed, the individual receives the higher of the two. The spousal benefit - if claimed at full retirement age - is equal to 50 percent of the spouse's PIA. Claiming up to 36 months before full retirement 
age results in a reduction of $25 / 36$ of one percent of the full benefit amount per month. Beyond 36 months, the benefit is reduced by $5 / 12$ of a percent of the base amount per month. Spousal benefits do not earn delayed retirement credits for commencements after full retirement age. An individual may claim spousal benefits at age 62 or later, provided that his or her spouse has either claimed worker benefits or reached full retirement age. For example, consider a oneearner couple in which the primary earner is aged 62 and the secondary earner is age 61. Assume that both spouses have a full retirement age of 66 . If the primary earner claims at age 62 , then the secondary earner may claim the spousal benefit at age 62 or later. If the primary earner delays to age 64 (before full retirement age), the secondary earner must wait until the same time to claim; that is, the secondary earner may claim at age 63 or later. On the other hand, if the primary earner delays until age 67, the secondary earner may claim at age 65 (when the primary earner has reached age 66). ${ }^{5}$ The spousal benefit was clearly designed with one-earner couples in mind. However, the spousal benefit offers an advantage for two earner couples as well: one spouse can claim spousal benefits at full retirement age while allowing his or her worker benefits to accumulate delayed retirement credits. ${ }^{6}$ The spouse who uses this strategy then switches to a worker benefit at or before age 70. Interestingly, either the primary or the secondary earner may use this strategy. ${ }^{7}$ For illustration, Table 1 shows the spousal and worker

\footnotetext{
${ }^{5}$ Technically, an individual must have claimed worker benefits in order for his or her spouse to claim spousal benefits. However, since 2000, an option known as "file and suspend" has allowed individuals to claim their worker benefits at full retirement age, but suspend payments. This option allows a spousal benefit to be claimed when the individual reaches full retirement age. Meanwhile, the individual's suspended worker benefit continues to be adjusted for delayed retirement. In the example given, the primary earner can claim worker benefits at age 66, but suspend payments until age 70, allowing the secondary earner to start receiving a (reduced) spousal benefit at age 65. The primary earner then would then receive 132 percent of his or her PIA at age 70, reflecting the full credit for delayed retirement.

${ }^{6}$ Claiming a spousal benefit before full retirement age requires that worker benefits be claimed at the same time. However, if the spousal benefit is claimed at full retirement age, then the worker benefit may be delayed.

${ }^{7}$ Munnell, Golub-Sass, and Karamcheva (2009) compute the gains to two-earner couples from having the high earner claim a spousal benefit at full retirement age, and letting his worker benefit grow until age 70 . They estimate that this provision has the potential to increase the present value of aggregate Social Security benefits by about $\$ 9.5$ billion for married couples in 2006.
} 
benefits that are payable in real terms, as a percent of PIA, for a claim made on each birthday from age 62 to 70 . These calculations apply to members of the 1943-54 birth cohorts. In the third and fifth columns, Table 1 also indicates the percent increase in benefits from delaying claiming by an additional year. For example, delaying claiming from age 62 to age 63 increases a worker benefit from 75 percent of PIA to 80 percent of PIA, an increase of 6.67 percent ((8075)/75=0.067).

In addition to spousal benefits, an individual may claim widow benefits on a deceased spouse's earnings record. Again, an individual who claims both a widow benefit and an worker benefit receives the higher of the two. The widow benefit - if claimed at the widow's full retirement age - is equal to 100 percent of the deceased spouse's PIA, plus any credits that the deceased spouse earned (as of the time of death) for delaying beyond full retirement age. A widow may claim benefits as early as age 60 with a benefit reduction of 28.5 percent. Widow benefits rise linearly between age 60 and full retirement age. However, a "widow limit provision" does not allow the widow's benefit to rise beyond a maximum amount. This maximum amount is the higher of the deceased spouse's actual benefit and 82.5 percent of the deceased spouse's PIA (see Weaver 2002 for additional details). For example, suppose the deceased spouse claimed at age 62 and was receiving a benefit of 75 percent of his own PIA. Assume the widow has a full retirement age of 66, implying that the widow's benefits are reduced by 4.75 percent (of the deceased spouse's PIA) per year for claiming before full retirement age. The widow would receive 71.5 percent of the deceased spouse's PIA at age 60 , 76.25 percent of the deceased spouse's PIA at age 61 , and 81 percent of the deceased spouse's PIA at age 62. This is an increase of 4.75 percent of the deceased spouse's PIA per year. However, if the widow delays to age 63 or later, the widow limit provision would apply, and the 
widow would receive only 82.5 percent of the deceased spouse's PIA. On the other hand, if the deceased spouse had claimed at full retirement age, the widow's benefit would have risen linearly until it reached 100 percent of the deceased spouse's PIA at the widow's full retirement age. There are no credits for delaying a widow's benefit beyond full retirement age.

To determine whether the adjustments to Social Security are actuarially fair, we simulate the Social Security benefits received under a variety of claiming strategies for the following five households:

1) Single Male

2) Single Female

3) Married one-earner couple (secondary earner has PIA of 0 )

4) Married two-earner couple (secondary earner has PIA equal to 75 percent of primary earner's PIA)

5) Married two-earner couple (secondary earner has PIA equal to 90 percent of primary earner's PIA)

All individuals in our simulations are members of the 1950 birth cohort, who turn 62 in 2012. Thus, both members of the couple households are the same age. ${ }^{8}$ We assume a birth date of 1/1/1950. We consider all possible claiming strategies that involve claiming on birthdays, even though benefits may actually be claimed at any point during the year. A claiming strategy for a single person is simply an age (between 62 and 70) for commencing benefits. A claiming strategy for a one-earner couple is an age (between 62 and 70) for the primary earner to claim worker benefits, and an age for the secondary earner to claim spousal benefits. The spouse's claiming age is restricted to be between $\min (a, 66)$ and 66 , where $a$ is the age at which the

\footnotetext{
${ }^{8}$ Coile et al. (2002) and Munnell and Soto (2005) show that a younger secondary earner makes it more advantageous for the primary earner to delay benefits.
} 
primary earner claims. A claiming strategy for a two-earner couple is more complicated. Each claiming strategy includes a set of two ages (between 62 and 70) for each individual to claim worker benefits. In addition, if one member of the couple claims worker benefits after full retirement age, he or she may also claim a spousal benefit starting at full retirement age. However, we assume that at most one member of the couple may claim a spousal benefit. Thus, if the husband and wife both delay their own benefits until age 68 , we must consider, alternatively, having the wife start spousal benefits at age 66 , and having the husband start spousal benefits at age 66 .

For each couple strategy, we also compute the widow benefit for the second-to-die in each potential year of entering widowhood. In each case, the first-to-die is assumed to die 6 months into the year, and the widow is assumed to claim widow benefits immediately. ${ }^{9}$ The widow follows the original strategy for claiming his or her own worker benefits. In each year of widowhood, the widow receives the greater of the widow benefit and his or her worker benefit if both benefits have been claimed. For example, consider the strategy in which both the primary and the secondary earner claim at age 70 , and suppose the primary earner dies at 67.5 . The widow commences widow benefits immediately, receiving 112 percent of the primary earner's PIA (reflecting the 18-month delay at the time of the primary earner's death). When the widow reaches age 70 (her original intended claiming age), she switches to her own worker benefit if that is higher. If the secondary earner's PIA is 90 percent of the primary earner's PIA, then her worker benefit would reach 118.8 percent (132 percent of 90 percent) of the primary earner's PIA at age 70; therefore, she switches to her own worker benefit. On the other hand, if the secondary earner's PIA is only 75 percent of the primary earner's PIA, then her worker benefit

\footnotetext{
${ }^{9}$ A more comprehensive analysis would consider alternative claiming dates for the widow. However, for simplicity, we assume that the widow follows the "naïve" strategy of claiming immediately. Shuart, Weaver, and Whitman (2005) provide a more detailed analysis of claiming strategies for widow benefits.
} 
would reach only 99 percent (132 percent of 75 percent) of the primary earner's PIA by age 70; in this case, the widow would stick to the widow benefit for the remainder of her life.

Table 2 indicates the widow benefit - as a percentage of the deceased spouse's PIA - that is payable for a variety of claiming ages and ages at death for the deceased spouse. If the deceased spouse claimed before full retirement age, the applicable widow limit is given in the last column. For example, if the deceased spouse claimed at age 63 and died at age 63.5, the widow limit provision would apply, and the widow benefit would be 82.5 percent of the deceased spouse's PIA. On the other hand, if the deceased spouse died at age 62.5 before claiming, the widow would receive 83.4 percent of the deceased spouse's PIA. In this case, the widow would be entitled to 100 percent of the deceased spouse's PIA if she waited until age 66 to claim benefits; however, we assume that she claims right away and receives a benefit that is reduced by 4.75 percent of the deceased spouse's PIA per year of early claiming.

For each claiming strategy, we then compute the present value of benefits for every possible year of death (or combination of years of death for couples). We consider real discount rates ranging from zero to 8 percent. For example, consider the married couple in case 4 (in which secondary earner's PIA is 75 percent of the primary earner's). For this couple, consider the strategy in which the secondary earner claims worker benefits at age 62 , the primary earner claims worker benefits at age 70, and the primary earner also claims spousal benefits at age 66 . Suppose further that the primary earner dies at age 75 and 6 months, and the secondary earner dies at age 85 and 6 months. The couple earns 56.25 percent ( 75 percent of 75 percent) of the primary earner's PIA from ages 62 through 65 . From ages 66 through 69, the primary earner's spousal benefit (equal to 50 percent of 75 percent - or 37.5 percent - of the primary earner's PIA) is added, resulting in a total income of 93.75 percent of the primary earner's PIA. From 
age 70 through the primary earner's death, the couple earns 188.25 percent of the primary earner's PIA, as the primary earner switches from the spousal benefit to his or her own worker benefit, which is now 132 percent of the primary earner's PIA. Finally, from the primary earner's death through the secondary earner's death, the widow earns 132 percent of the primary earner's PIA. At a 4 percent real interest rate, this stream of income results in a present value of 219.77 times the primary earner's PIA. For example, if the primary earner's PIA is $\$ 1,900$, then the present value is $\$ 417,567.11$.

Finally, using cohort life tables (by gender) for individuals born on 1/1/1950, we compute the expected present value over the distribution of ages at death. Our cohort life tables were provided by the Social Security Administration and reflect the intermediate assumptions in the 2011 Trustees Report. ${ }^{10}$ In the couple calculations, the primary earner is assumed to be male and the secondary earner is assumed to be female; this assumption likely reflects the situation of the majority of married couples in the 1950 birth cohort. The deaths of the husband and wife are assumed to be independent events. For example, the probability of a 62-year-old man dying between ages 65 and 66 (conditional on surviving to 62 ) is 0.0137 , and the probability of a 62 year-old woman dying between ages 70 and 71 (conditional on surviving to 62) is 0.0139 . In our analysis, we treat these as the probabilities of dying at age 65 and 6 months (for the man) and at age 70 and 6 months (for the woman). For a couple, then, the joint probability of the husband dying at age 65 and 6 months and the wife dying at age 70 and 6 months is $(0.0137)(0.0139)=0.00019$.

\section{b. Results and Discussion}

\footnotetext{
${ }^{10}$ These life tables are also used in the Social Security Administration's life expectancy calculator, which is available at http://www.ssa.gov/oact/population/longevity.html.
} 
Figure 1 shows the cumulative distribution of life expectancy for men and women in the 1950 birth cohort, conditional on reaching age 62. As expected, women are more likely to survive to more advanced ages. The life expectancy for women in this cohort, conditional on reaching age 62 , is 85.51 ; for men, it is 83.20 . Conditional on reaching age 62 , the probability of reaching age 90 is 26.8 percent for men and 35.7 percent for women. The probability of reaching age 100 is 2.3 percent for men and 4.8 percent for women.

Figure 2 illustrates the claiming ages that maximize expected present value as a function of the real interest rate for cases 1 and 2 (single men and single women). In general, women benefit more from delaying benefits, due to their longer life expectancies. For real interest rates of 0.8 percent or below, women maximize expected present value by delaying until age 70 ; on the other hand, even for a real interest rate of zero, men with average mortality risk maximize present value by delaying only until age 69. Delays of any length no longer increase present value for interest real rates above 3.5 percent for men and 4.2 percent for women.

To show the magnitude of the potential gains from delay, Figure 3 indicates the maximum gain from delay as a fraction of the present value present value of claiming at age 62 . As expected, the gains from delay are larger at lower interest rates and for women compared to men. At a real interest rate of zero percent (approximating today's market conditions), the maximum possible gain from delay is 18.3 percent for women and 13.3 percent for men. When the real interest rate rises to 3 percent, men and women stand to gain only 1.1 and 3.6 percent respectively from delay.

Figure 4 illustrates the present value from claiming at the age given on the horizontal axis, as a fraction of the present value of claiming at age 62 . This calculation is shown for three different interest rates -0 percent, 1 percent, and 2.5 percent. As expected, the relative present value 
tends to rise (fall) with age at lower (higher) interest rates. However, the present value changes unevenly with age, with nonconvexities arising at ages 63 and 66. These nonconvexities are created by the Social Security benefit formula and are apparent in Table 1: the percent increase in benefits from delaying claiming by an additional year changes unevenly with age, and is lowest at ages 63 and 66 . This structure suggests that claiming at ages 63 or 66 generally will not maximize present value, a result that can be seen in Figure 2 as well - the present value maximizing claiming age is never 63 or 66 .

Couples face a more complex claiming decision, as a separate claiming age must be chosen for each member. Figure 5 illustrates the claiming ages that maximize present value for the primary and secondary earners in each of the three couple households (cases 3-5). The primary and secondary earners' claiming ages shown in the graphs are part of a joint strategy to maximize the present value of the household's Social Security benefits. For the one-earner couple, the figure illustrates the age at which the primary earner claims worker benefits, and the age at which the non-working spouse claims spousal benefits. If the goal is to maximize present value, the primary earner should delay to age 70 for real interest rates of 2.5 percent or less. Delays no longer increase present value for real interest rates above 5.3 percent. The nonworking spouse should generally claim spousal benefits at age 66 if the primary earner delays to 66 or later, or the same time the primary earner if the primary earner claims before age 66 .

For two-earner couples, the claiming ages shown in Figure 5 are for worker benefits. However, all strategies call for at least one member of the couple to claim spousal benefits at age 66 if possible (i.e., if one member of the couple delays worker benefits past full retirement age). For example, consider the two-earner couple in which the secondary earner's PIA is 75 percent of the primary earner's. At low real interest rates ( 0.6 percent and below), the household 
maximizes present value when both individuals delay their worker benefits to age 70 . This result is shown in the figure. In addition, the secondary earner claims spousal benefits starting at age 66. This result is not show in the figure, but is included in the present value calculations. For real interest rates between 0.6 percent and 6.3 percent, if the goal is to maximize present value, the primary earner should delay to age 70 while the secondary earner should claim earlier. In addition, the primary earner should claim spousal benefits at age 66: as the secondary earner claims worker benefits before full retirement age, the household gains the most from having the primary earner claim spousal benefits during the delay period. For real interest rates above 6.3 percent and below 6.6 percent, however, this recommendation is reversed: the secondary earner should delay to age 70 while the primary earner claims immediately. In addition, the secondary earner (who is now delaying beyond full retirement age) should claim spousal benefits starting at age 66. Delays cease to improve present value for real interest rates of 6.6 percent or greater. The results for case 5 (in which the secondary earner's PIA is 90 percent of the primary earner's) are similar. The main qualitative difference occurs at low interest rates: the secondary earner should claim before age 70 even for an interest rate of zero, while the primary earner should claim spousal benefits at age 66 and delay his worker benefit to age 70 . Even though both members of the couple delay past full retirement age, it is more valuable for the primary earner to claim spousal benefits, as his delay period is longer than that of the secondary earner.

Figure 6 illustrates the maximum achievable gain in present value, relative to both members of the couple claiming at age 62. At a real interest rate of 0 percent, the two-earner couples gain around 21-22 percent by following the present value maximizing strategy. The gains to the oneearner couple are slightly smaller - around 20 percent. At a real interest rate of 2.5 percent, one earner couples gain around 8 percent, while the two earner couples gain around 12 percent. 
The intuition behind the couple results is as follows. When the primary earner of a couple delays worker benefits, this is equivalent to purchasing a joint life annuity with a 100 percent survivor benefit; that is, both the first-to-die and the surviving spouse benefit from the delay. At plausible real interest rates (under 6 percent), delaying the secondary earner's benefit buys a first-to-die annuity. That is, if the secondary earner dies, her worker benefit ceases, and the primary earner continues to receive his own worker benefit. If the primary earner dies, the secondary earner switches to a higher widow benefit. Similarly, delays for single workers purchase only single life annuities. As the first-to-die, single life, and joint-life annuities are offered on the same terms (the cost of delay is the same), the joint life annuity is clearly the most attractive. Thus, delaying is more valuable for couples relative to singles, and for primary earners relative to secondary earners. At real interest rates above 6 percent, couples may maximize present value when the primary earner claims immediately (producing the greatest amount of short-term income for the couple), while the secondary earner delays, providing a joint life annuity that boosts the income of the primary earner in widowhood. However, we consider such interest rates to be implausibly high.

The gains to both two-earner couples (cases 4 and 5) are similar, as a result of two largely offsetting effects. The couple in case 4 (in which the secondary earner's PIA is 75 percent of the primary earner's) gains more from widow benefits to the secondary earner. This is because the secondary earner in case 5 (in which the secondary earner's PIA is 90 percent of the primary earner's) is in a better position to rely on her worker benefit during widowhood. On the other hand, the couple in case 5 has a larger gain from any spousal benefits that the primary earner claims during the delay period. As spousal benefits are claimed at age 66, while widow benefits are likely to be claimed much later, the couple in case 4 gains more at lower interest rates (which 
give relatively more weight to the distant widow benefits) while the couple in case 5 gains more at higher interest rates (which give relatively more weight to the immediate spousal benefits).

Figure 7 illustrates the present value of claiming at the age given on the horizontal axis, relative to both members of the couple claiming as early as possible. The left three graphs show this calculation for the primary earners of the three couples at interest rates of 0,1 , and 2.5 percent. In each of these graphs, the secondary earner is assumed to claim at the earliest possible age - i.e., 62 for the two-earner couples, and the minimum of 66 and the primary earner's claiming age for the one-earner couple. The primary earner is assumed to commence spousal benefits at age 66 whenever possible (i.e., when he claims worker benefits at age 67 or later). At lower interest rates, one-earner couples gain more from additional delays in the primary earner's claiming age, particularly for delays up to full retirement age. At higher interest rates and for delays beyond full retirement age, two-earner couples gain the most from delays. The gains from delay are similar for both two-earner couples. The three graphs on the right-hand-side of Figure 7 show the same calculation for the secondary earners in the two-earner couples (cases 4 and 5). In each case, the primary earner is assumed to claim at age 62 , and the secondary earner is assumed to commence spousal benefits at age 66 whenever possible.

We emphasize that maximizing expected present value is not necessarily the optimal (expected utility maximizing) strategy. Coile et al. (2001) demonstrate that the delays that maximize expected utility are generally longer than those that maximize expected value, as risk aversion increases the benefit from annuities. However, there are a number of other factors may also influence the optimal claiming strategy, including a desire for precautionary saving or bequest motives. For example, some households with strong bequest motives may find the annuities implicit in delaying to be less valuable (see Coile et al. 2001, for further discussion). 
On the other hand, if delaying is actuarially advantageous, it may boost the household's wealth and increase the ability to leave a bequest. A household with a strong desire for precautionary saving would find the annuities implicit in delaying to be less valuable. Our analysis of the expected gains from delay merely shows whether delaying is actuarially advantageous. To the extent that expected monetary payoffs matter, we would expect to see more delays among those with larger expected gains.

An interesting implication of our results concerns the optimal use of Social Security and 401(k) balances during retirement. A household that wishes to delay claiming needs to be able to finance the deferral. In the presence of liquidity constraints, other retirement assets such as 401(k) balances may be used. Households are often advised to annuitize 401(k) balances, consuming them in parallel with Social Security. However, deferring Social Security - which is equivalent to purchasing an annuity - may generate a higher payoff compared to buying a private annuity. This is particularly true during a period of low interest rates, as firms offering private annuities reduce the payments that are offered, while the terms of Social Security deferral do not change. Thus, during periods of low interest rates, households may be better off spending down 401(k) assets first and deferring Social Security, effectively substituting Social Security deferral for the purchase of private annuities.

These results are consistent with those of earlier studies. Meyer and Reichenstein (2010) demonstrate that, assuming a real interest rate of 2.43 percent, a 62-year-old male with from the 1943-54 birth cohorts (assumed to have a remaining life expectancy of 20 years) maximizes present value by claiming at age 65, while a 62-year-old female from the same group (assumed to have a remaining life expectancy of 23 years) maximizes present value by claiming at 68 . On the other hand, a two-earner couple gains from delaying the primary earner's benefit. In 
particular, suppose the secondary earner's PIA is 90 percent of the primary earner's. If the secondary earner claims worker benefits at age 62 , and the primary earner begins spousal benefits at age 66 and switches to worker benefits at 70, the present value of the couple's Social Security income increases by about 15 percent relative to both starting benefits at age 62 . Our analysis suggests that at a real interest rate of 2.4 percent, a single male should delay to age 67 , and a single female should delay to age 68 . At the same interest rate, we also find a gain of around 13 percent from optimal delay relative to claiming at age 62 for the couple in case 5 (in which the secondary earner's PIA is 90 percent of the primary earner's PIA). Munnell and Soto (2005) find that with a real interest rate of three percent, a two-earner couple from the 1948 birth cohort, in which the wife's PIA is greater than 40 percent of the husband's, maximizes the present value of benefits when the husband claims at age 69 and the wife claims at age 65 . Our analysis suggests that such a couple maximizes present value when the husband claims at 70 and the wife claims at 62 .

Compared to Coile et al. (2002) and Sass, Sun, and Webb (2007), we find that delay has a greater monetary payoff, and therefore, our present value maximizing delays are longer. For example, Coile et al. find that to maximize present value, the (male) primary earner in a couple from the 1930 birth cohort should delay only to full retirement age, even at a real interest rate of 1 percent. A single male from the same cohort should delay to full retirement age at a real interest rate of 1 percent, and for only 10 months at a real interest rate of 3 percent. Similarly, using a real interest rate of 3 percent, Sass, Sun, and Webb (2007) show that for the average couple in the HRS (in which the husbands' birth years fell between 1930 and 1941), the present value of benefits is maximized when the husband claims at 66 and the wife at 62 . The main reason our results are different is that these other two studies focus on older cohorts, while we 
focus on the 1950 birth cohort. The terms for delay beyond full retirement age are more generous for the 1950 birth cohort - they earn a credit of 8 percent of PIA per year, compared with 4.5 percent of PIA per year for the 1930 cohort. $^{11}$ Moreover, the 1950 cohort has lower mortality than the 1930 cohort, making delay even more favorable. Nevertheless, our results are qualitatively similar: delays are actuarially advantageous for a large subset of the population, particularly at low real interest rates.

\section{Empirical Analysis}

\section{a. Data}

We explore actual claiming behavior using data from the Health and Retirement Study (HRS), a panel survey that is intended to be representative of the population aged 50 and older. The survey was begun in 1992 and is conducted every other year, with new respondents added periodically to keep the sample representative of the target population. We use the RAND version of the HRS, and our analysis generally incorporates information from all 9 available waves (1992-2008) of the survey.

For each individual, the RAND version of the HRS includes the age (in months) at which Social Security benefits were commenced; this information is available for all individuals who have ever received Social Security benefits. Unfortunately, we are unable to distinguish among retired worker benefits, spousal benefits, survivor benefits, and disability benefits. Therefore, we exclude from our analysis all individuals who have ever received disability benefits, all individuals who claimed before age 62, and all individuals who report a marital status of widowed in any wave before they claimed Social Security benefits. Any remaining individuals

\footnotetext{
${ }^{11}$ Note that the terms for delay at earlier ages are slightly different as well. Full retirement age was 65 for the 1930 cohort, with 80 percent of PIA payable at age 62 .
} 
are most likely to be receiving retired worker or spousal benefits, which are the focus of our analysis. We also exclude individuals who claimed after age 70. For individuals who are under 70 and have not claimed by the last wave of the survey, we cannot tell if they are delaying benefits or simply ineligible. Therefore, we drop all individuals whom we do not observe over the full range from ages 62 through $70 .^{12}$ Then, we exclude all individuals who do not claim benefits by age 70 , as they are most likely ineligible for benefits.

The dependent variables in our regressions are all measures of claiming delay. We consider two alternative definitions of claiming delay. First, for all individuals, we measure delay as the number of months since age 62 that the individual claims benefits. Second, for individuals who are not working at the time of their claim, we measure delay as the number of months since the later of turning 62 or stopping work. ${ }^{13}$ We also construct two dummy variables, one indicating that a claim was made within two months of turning 62, and another indicating that claiming was delayed to full retirement age or later.

As the claiming decision is made from age 62 onwards, we measure many of our explanatory variables (including assets, subjective assessment of life expectancy, work history and expectations, subjective assessment of the probability of leaving a bequest, and economic conditions) as close to age 62 as possible. We merge in monthly nominal interest rate and unemployment rate data, matched by the month of turning 62. The nominal interest rate is

\footnotetext{
${ }^{12}$ More specifically, we restrict our sample to individuals whose age in the first wave in which they are observed is less than or equal to 62, and whose age in the last wave in which they are observed is 70 or greater.

${ }^{13}$ The HRS does not directly indicate whether individuals were working at the time of their claim. However, we know whether individuals are working in the first wave in which they are observed following their claim. For those not working in this wave, we know the age at which they last worked. Individuals working in the wave following their claim are classified as working at the time of their claim. Individuals not working in the wave following their claim are classified as working at the time of their claim if and only if the age at which they claimed is strictly less than the age at which they last worked. All other individuals are classified as not working at the time of their claim. It is possible that some individuals not working at the time of their claim went back to work later, or that some individuals working in the wave following their claim were not working at the time of their claim. Thus, stopping work does not necessarily mean permanent retirement.
} 
defined as the yield on 6-month Treasury Bills, obtained from the Federal Reserve. ${ }^{14}$ The unemployment rate is the national seasonally adjusted rate, obtained from the Bureau of Labor Statistics. For other variables, we identify the wave immediately preceding each individual's $62^{\text {nd }}$ birthday (which we refer to as the "age-62 wave") as follows. Consider an individual who was observed in waves $t$ and $t-1$, was under age 62 in wave $t-1$, and was 62 or older in wave $t$. In this case, the age-62 wave is $t-1$. (The time interval between waves $t$ and $t-1$ is two years on average, but can vary depending on the timing of interviews.) Now consider an individual who was observed in wave $t-1$ but not in wave $t$, was under age 62 in wave $t-1$, and turned 62 within two years of wave $t-1$. In this case, wave $t-1$ is the age- 62 wave. Roughly speaking, we define the age-62 wave as the wave that is immediately preceding the wave following the individual's $62^{\text {nd }}$ birthday. Any individual who is not observed in his or her age-62 wave is dropped.

We measure each individual's marital status (married or single), household financial net worth, ${ }^{15}$ work status (working or not), self-assessed probability of working full time after age 62 , and self-assessed probability of living to age 75 at the time of the age-62 wave. For the selfassessed probabilities, we construct a set of indicator variables for whether these are above or below 50 percent. For financial net worth, we include a set of indicator variables for the household's quintile in the net worth distribution. We also construct an indicator variable for whether an individual has worked for at least 35 years by the age- 62 wave. In addition, we utilize HRS questions about the subjective probability of leaving a bequest to construct indicator variables for whether the probability of leaving a "large" bequest is less than 50 percent, or 50 percent or more. From the 1994 wave onwards, respondents are asked to assess the probability

\footnotetext{
${ }_{15}^{14}$ Interest rate data were retrieved from http://www.federalreserve.gov/releases/h15/data.htm.

${ }^{15}$ Financial net worth is defined as the value of stocks, bonds, mutual funds, checking accounts, savings accounts, money market accounts, CDs, savings bonds, Treasury bills, IRA and Keogh accounts, and other savings, net of non-housing debt.
} 
(on a $0-100$ scale) of leaving a bequest of $\$ 100,000$ or more. We use these responses to construct our indicator variables. In the 1992 wave, however, respondents are asked about the probability of leaving a "sizeable" bequest, with possible responses ranging from 1 (yes definitely) to 5 (no - definitely). We code responses of 1 (yes - definitely) through 3 (yes possible) as a probability of 50 percent or more. This coding results in similar probabilities across waves: among individuals whose age- 62 wave is 1992 , around 49 percent have a 50 percent or greater chance of leaving a large bequest. Among individuals whose age-62 wave is not 1992, around 45 percent have a 50 percent or greater chance of leaving a bequest of $\$ 100,000$ or more.

Other explanatory variables used in our analysis are time-invariant, including gender, race, and education level. We also construct a measure of individuals' subjective discount rates using questions from multiple waves for each individual. In some waves of the HRS, respondents are asked about their financial planning horizon. Possible answers include the next few months, the next year, the next few years, the next 5 to 10 years, and longer than 10 years. We construct an indicator for whether the respondent's planning horizon is longer than the next few years. If responses to the planning horizon question are available in multiple waves for a respondent, we use the median of the available responses in constructing our indicator.

Our final sample consists of 2,702 individuals. Table 3 shows summary statistics for all variables used in our analysis. We perform some of our analysis on subsamples: individuals who stopped working at or before age $62,{ }^{16}$ individuals who were not working at the time of their claim, and males (who, for this cohort, are more likely to be collecting benefits on their own record). The fractions of the full sample in each of these categories are also given in Table 3.

\footnotetext{
${ }^{16}$ We say an individual stopped work before age 62 if he or she was not working at the time of claiming benefits (see footnote 8 ) and, in the wave following the claim, either reports never having worked, or reports an age last worked of 62 or earlier. Such individuals may return to work later.
} 
The birth years for individuals in our sample range from 1930-39. As discussed earlier, the terms on which these cohorts could delay Social Security are somewhat different from the ones used in our simulations (for the 1950 birth cohort). In particular, the full retirement age for most of these cohorts is 65 , and the credits for delaying retirement beyond full retirement age have become more generous. These differences may affect the specific present-value maximizing strategies for the individuals in our sample, but we do not expect this to affect our general predictions about groups for whom delay is actuarially advantageous. Indeed, Coile et al. (2002) show that while delaying beyond full retirement age may not be actuarially advantageous for the1930 cohort, it is often actuarially advantageous to delay for a shorter period.

\section{b. Methodology}

We begin by estimating probit regressions in which the dependent variable is an indicator for whether benefits were claimed within two months of turning $62 .{ }^{17}$ We estimate these regressions for the full sample, for individuals who stopped working before age 62 , and for males. For individuals who were not working at the time of their claim, we estimate probit regressions in which the dependent variable is an indicator for whether benefits were claimed within two months of the later of stopping work or reaching age 62. For the full sample and all subsamples, we also estimate probit regressions in which the dependent variable is an indicator for whether benefits were delayed beyond full retirement age. ${ }^{18}$ Finally, we estimate Tobit regressions in which the dependent variable is the number of months of delay (censored at zero). For the full sample, for individuals who stopped working before age 62 , and for males, the dependent variable is the number of months since age 62 that benefits are claimed. For

\footnotetext{
${ }^{17}$ This specification is similar to that of Hurd, Smith, and Zissimopoulos (2004).

${ }^{18}$ This specification is similar to that of Sass, Sun, and Webb (2007).
} 
individuals who were not working at the time of their claim, the dependent variable is the number of months since the later of age 62 and stopping work.

Our simulations suggest that delaying claiming is more valuable for single women relative to single men, and for couples relative to singles. Moreover, for plausible real interest rates, delaying the primary earner's benefit has a greater benefit than delaying the secondary earner's benefit. Thus, if claiming decisions are influenced by the present value of benefits, we would predict that married men (who are more likely to be the primary earner in couples who claimed during the past 20 years) tend to delay claiming more than either married women, single men or single women. Moreover, we would predict that single women tend to delay more than single men. Racial differences in life expectancy at retirement (see e.g., Srestha 2006) suggest that African-Americans may be more likely to claim early than whites. In addition, we would predict that longer subjective life expectancies, longer planning horizons (lower subjective discount rates), and lower interest rates at age 62 are associated with delays. In the presence of liquidity constraints, a high level of financial wealth can make delay easier by providing income during the delay period; thus, greater wealth may be associated with delays. Annuities may be less attractive to individuals planning to leave a bequest, implying that a higher probability of leaving a bequest would be associated with early claiming. On the other hand, boosting lifetime wealth through actuarially advantageous delays may also be more attractive to those wishing to leave a bequest. We would expect delays to increase with education, as higher levels of education are associated with both longer life expectancy and with financial literacy.

We would also expect claiming decisions to be linked to labor supply decisions and labor market conditions. Once an individual has stopped working, liquidity constraints may make claiming more attractive. Moreover, individuals claiming before the year 2000, and individuals 
claiming prior to reaching full retirement age in 2000 and later, are subject to the earnings test, which reduces benefits for wages received above a certain threshold. Any months of benefits forgone due to the earnings test are treated as months of delay (and therefore increase benefits paid at full retirement age); thus, the earnings test effectively forces delays in claiming. ${ }^{19}$ For both of these reasons, we would expect working in the age-62 wave, as well as a higher selfreported probability of working after age 62 , to be associated with claiming delays. Similarly, poor labor market conditions (high unemployment) may encourage early retirement, and therefore early claims. We would also expect having worked for 35 years or more to be associated with early claims. The Social Security benefit formula imposes high implicit tax rates on work beyond 35 years (see, e.g., Goda, Shoven, and Slavov 2011), suggesting that retiring (and therefore claiming) becomes more attractive after reaching 35 years of work.

\section{c. Results}

Figure 8 presents a histogram of months of delay (months elapsed between age 62 and claiming) for the full sample. Figure 9 does the same for individuals who stopped working before age 62, and Figure 10 does the same for males. Figure 11 presents a histogram of the number of months elapsed between claiming and the later of age 62 and stopping work. This is done for the subsample of individuals who were not working at the time of their claim. In the full sample, 42.6 percent of individuals claim within two months of reaching age 62. Another spike in claims occurs at full retirement age ( 65 for most individuals in the sample), with almost 24 percent of individuals claiming at full retirement age or later. A smaller spike occurs around age 63 . The pattern is similar among males. The age-63 spike in claiming is inconsistent with

\footnotetext{
${ }^{19}$ In addition, the earnings test is not well understood (see, e.g., Biggs 2008), and individuals may respond to the earnings test as if it were a tax on work.
} 
present value maximization, which would imply that claiming at age 63 is suboptimal. Among those who stopped work before age 62 or were not working at the time of their claim, more than 75 percent delay by 2 months or less.

Table 4 presents results from our probit model in which the dependent variable is the indicator for claiming early. The coefficients presented in the table are marginal effects, and standard errors are clustered by household. For the full sample, when labor supply variables are excluded (column (1)), married women tend to claim early. However, once labor supply variables are introduced (column (2)), the significance of gender and marital status disappears, suggesting that married women may claim early because they tend to stop work early. More generally, we find little evidence of a direct relationship between gender or marital status and claiming. On the other hand, work plans are strongly associated with claiming early. Working in the age-62 wave, or having a high self-reported probability of working after age 62 , substantially reduces the probability of claiming early. Reporting a probability of work after age 62 of 50 percent or more is associated with a 27.8 percentage point reduction in the probability of claiming early; relative to the mean probability of claiming early (42.56 percent), this represents an increase of 65.3 percent. Working in the age- 62 wave has an impact of a similar magnitude. A 35-year (or longer) career increases the probability of claiming early by about 4.5 percentage points (10.6 percent). Some college education also somewhat raises the probability of claiming early, by 6.7 percentage points (15.8 percent) after controlling for labor force participation. While assets can be used to finance claiming delays, it does not appear that they are used in this way. Higher levels of assets tend to somewhat increase the probability of claiming early (column (1)), possibly because assets are also indicative of the ability to stop work in the near future, and stopping work appears to be strongly associated with claiming. 
Indeed, the significance of the asset dummies largely disappears after controlling for labor supply choices (column (2)).

Among those who stopped work before age 62 , married women are less likely to claim early (column (3)), although this effect again seems to operate through labor force participation. Once the labor force participation variables are introduced, gender and marital status no longer have a significant effect, while those who have worked a 35-year career (who are disproportionately male) are more likely to claim early (column (4)). Again, assets tend to increase the probability of claiming early, and this effect persists even after controlling for labor supply. Having a high probability of leaving a bequest somewhat reduces the probability of claiming early in this group, although the effect is only significant at the 10 percent level. College education does not have a statistically significant relationship with claiming early in this group. The effects for individuals not working at the time of their claim (columns (5) and (6)) are similar, although married women in this group are 9.9 percent more likely than married men to claim early even after controlling for labor force participation. The effects for males (columns (7) and (8)) are similar to those for the full sample (columns (1) and (2)).

Table 5 shows the results from estimating probit regressions in which the dependent variable is an indicator for delaying until full retirement age or beyond. After controlling for labor force participation, married women in the full sample (column (2)) are 4.8 percentage points (around 20 percent) less likely to delay claiming than married men. This result is consistent with our simulations. However, all the other gender and marital status coefficients are insignificant after controlling for labor force participation. Having some college education consistently increases the probability of delay. In the full sample, after controlling for labor force participation, those with some college are 7.1 percentage points ( 29.5 percent) more likely to delay than those with 
no college. Having a high self-assessed probability of surviving to age 75 increases the probability of delay in the full sample and among men, but only before controlling for labor force participation. Once the labor supply variables are introduced, the significance disappears, suggesting that subjective mortality affects claiming only through labor supply decisions. Again, the labor force participation variables are mostly significant in the expected direction. Delaying is strongly associated with working in the age-62 wave, and with planning to work after age 62 . On the other hand, a 35-year career reduces the probability of delay.

Finally, Table 6 reports the results from Tobit regressions in which the dependent variable is the number of months of delay. The dependent variable is censored at zero. Delay is defined relative to age 62 for the full sample, for those who stopped working before age 62 , and for males. Delay is defined relative to the later of stopping work and turning 62 for those who were not working at the time of their claim. The results are largely consistent with those of Tables 4 and 5. Controlling for labor supply, married women in the full sample claim around 2.4 months earlier than married men. However, this result does not emerge among those who retired before age 62 or who were not working at the time of their claim. After controlling for labor force participation, individuals with some college claim between 1.7 and 4.5 months later, depending on the subsample, than individuals with no college. Working in the age-62 wave and planning to work after age 62 are associated with delays, while a 35 -year career is associated with early claiming. After controlling for labor force participation, higher wealth levels appear to be associated with earlier claims among those who stopped work before age 62 , but not among the other groups.

Our results are generally similar to those of Hurd, Smith, and Zissimopoulos (2004) and Sass, Sun, and Webb (2007). Like Sass, Sun, and Webb (2007), but unlike Hurd, Smith, and 
Zissimopoulos (2004), we do not find a relationship between the subjective survival probabilities and claiming. One possible explanation is that Hurd, Smith, and Zissimopoulos use the subjective probability of surviving to age 85 , while we (like Sass, Sun, and Webb 2007) use the subjective probability of surviving until age 75 (which is collected consistently across all the waves in our analysis). Another difference between our analysis and that of Hurd, Smith, and Zissimopoulos (2004), is that we use the interest rate - rather than stockowner status - to measure the return on private saving, and we find no evidence of a relationship to claiming behavior. Like Munnell and Soto (2005), we find that married women tend to claim early; however, this effect disappears once we control for labor supply decisions. Our results differ from those of Coile et al. (2002). However, their analysis is based on a different dataset for a much older cohort - individuals retiring in the early 1980s.

\section{Conclusions}

We have shown that delaying Social Security is actuarially advantageous for a large subset of the population. In particular, for most plausible real interest rates, two-earner households with average life expectancy maximize the present value of Social Security benefits when the primary earner delays claiming until age 70. Primary earners in one-earner couples can also maximize the present value of their household's benefits by delaying, though the actuarially advantageous delay period is shorter and the gains are smaller. Delaying is less attractive for secondary earners in two earner couples, and for singles. However, at real interest rates of 1.6 percent or less, two-earner households maximize present value when secondary earners delay as well. Single men and women benefit from at least a short delay (to age 64) for real interest rates of, respectively, 3.5 percent or less and 4.1 percent or less. 
However, we find little empirical evidence that actual claiming behavior is related to the actuarial advantage of delay. Indeed, most individuals appear to claim shortly after reaching age 62 or stopping work. Labor supply appears to be the primary determinant of the claiming decision. We do find a consistent relationship between education levels and delayed claiming, possibly because education may be associated with financial literacy or a longer life expectancy. It is not clear why individuals do not appear to consider actuarial advantage in their claiming decisions. It is possible that this is another manifestation of the annuity demand puzzle, or that individuals merely lack understanding of Social Security's complex rules. 


\section{References}

Biggs, Andrew G. 2008. "The Social Security Earnings Test: The Tax That Wasn't", Tax Policy Outlook 3 (July), Washington D.C.: American Enterprise Institute, http://www.aei.org/files/2008/07/17/20080717_No-323312TPOJulyg.pdf

Brown, Jeffrey R. 2007. "Rational and Behavioral Perspectives on the Role of Annuities in Retirement Planning.” Working Paper 13537. Cambridge: National Bureau of Economic Research. . 2008. "Financial Education and Annuities." Consultant Report. Paris: OECD.

Brown, Jeffrey R., Marcus D. Casey, and Olivia S. Mitchell. 2007. "Who Values the Social Security Annuity: New Evidence on the Annuitization Puzzle.” Unpublished Manuscript.

Brown, Jeffrey, R., Arie Kapteyn, and Olivia Mitchell. 2011. "Framing Effects and Expected Social Security Claiming Behavior." Working Paper 17018. Cambridge: National Bureau of Economic Research.

Bütler, Monika and Federica Teppa. 2007. "The Choice Between an Annuity and a Lump Sum: Results from Swiss Pension Funds.” Journal of Public Economics 91(10): 1944-1966.

Coile, Courtney, Peter Diamond, Jonathan Gruber and Alain Jousten. 2002. "Delays In Claiming Social Security Benefits." Journal of Applied Econometrics 84(3): 357-385.

Goda, Gopi Shah, John Shoven, and Sita Nataraj Slavov. 2011. "Implicit Taxes on Work from Social Security and Medicare." In Tax Policy and the Economy, ed. Jeffrey Brown, 69-88. Chicago: University of Chicago Press.

Hurd, Michael D., James P. Smith and Julie M. Zissimopoulos. 2004. "The Effects of Subjective Survival on Retirement and Social Security Claiming." Journal of Applied Econometrics 19(6): 761-775.

Jivan, Natalia A. 2004. “How Can the Actuarial Reduction for Social Security Be Right?” Just the Facts 11, Center for Retirement Research. Chestnut Hill: Boston College.

Liebman, Jeffrey B. and Erzo F.P. Luttmer. 2011. "Would People Behave Differently If They Better Understood Social Security? Evidence From a Field Experiment." Unpublished Manuscript.

Meyer, William and William Reichenstein. 2010. "Social Security: When to Start Benefits and How to Minimize Longevity Risk." Journal of Financial Planning 23(3): 49-59.

Mitchell, Olivia S., James M. Poterba, Mark J. Warshawsky, and Jeffrey R. Brown. 1999. "New Evidence on the Money's Worth of Individual Annuities." American Economic Review 89(5): 1299-1318. 
Munnell, Alicia H., Alex Golub-Sass and Nadia Karamcheva, N. 2009, "Strange but True: Claim Social Security Now, Claim More Later." Issue Brief 9-9, Center for Retirement Research. Chestnut Hill: Boston College.

Munnell, Alicia H. and Mauricio Soto. 2005. "Why Do Women Claim Social Security Benefits So Early?" Issue Brief 35, Center for Retirement Research. Chestnut Hill: Boston College.

Sass, Steven A., Wei Sun, and Anthony Webb. 2007, "When Should Married Men Claim Social Security Benefits?" Working Paper 2007-17, Center for Retirement Research. Chestnut Hill: Boston College.

Shrestha, Laura B. 2005. "Life Expectancy in the United States. 2005.” Report RL32792. Washington D.C.: Congressional Research Service.

Shuart, Amy N., David A. Weaver, and Kevin Whitman. 2010. "Widowed Before Retirement: Social Security Benefits Claiming Strategies." Journal of Financial Planning 23(4): 45-53.

Weaver, David A. 2002. “The Widow(er)'s Limit Provision of Social Security.” Social Security Bulletin 64(1): 1-15.

Yaari, Menahem E. 1965. "Uncertain Lifetime, Life Insurance, and the Theory of the Consumer." Review of Economic Studies 32(2): 137-150. 
Figure 1: Cumulative Distribution of Age at Death

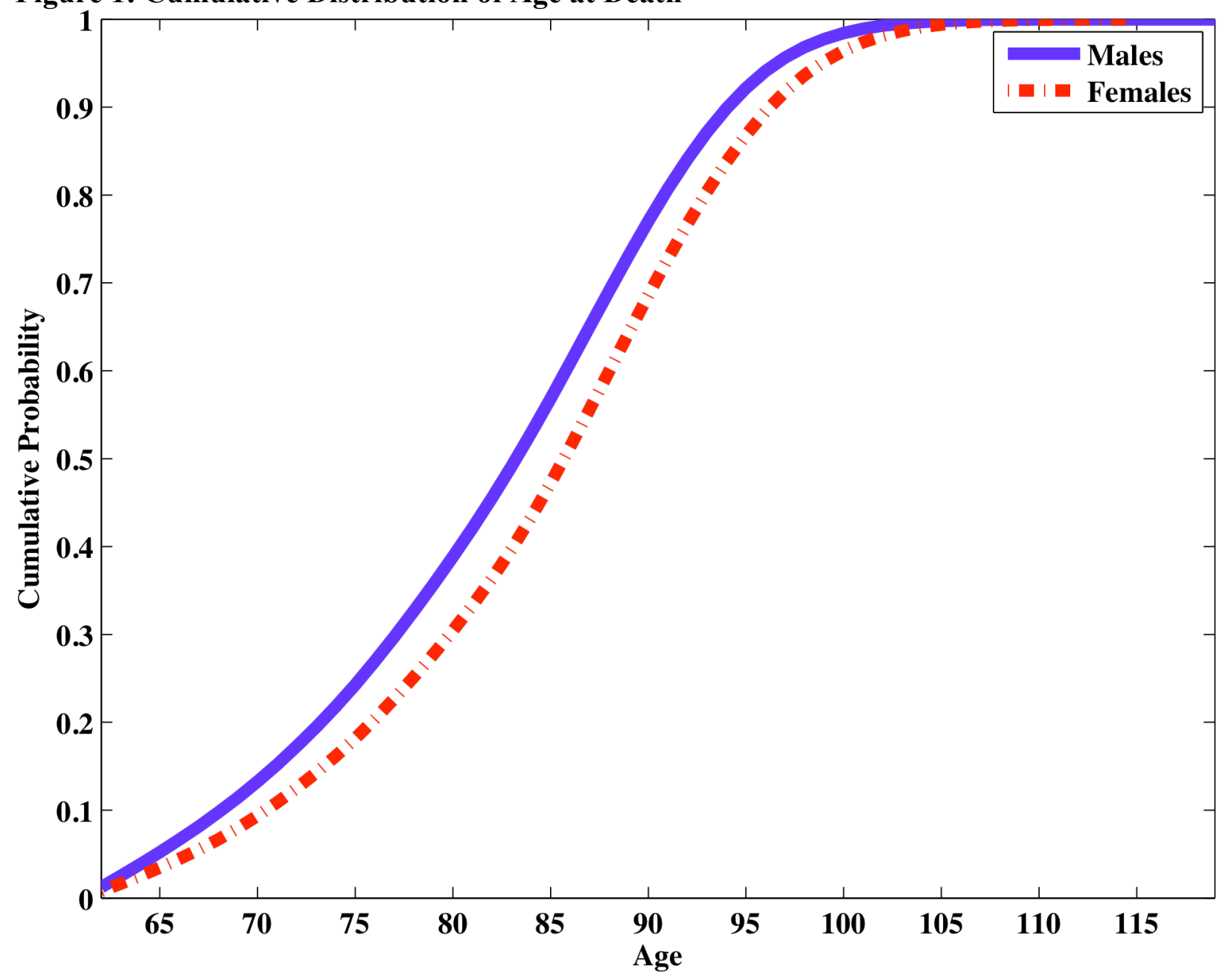

Notes: Authors' calculations based on Social Security Administration's 1950 cohort life table. 
Figure 2: Present Value Maximizing Claiming Ages for Singles

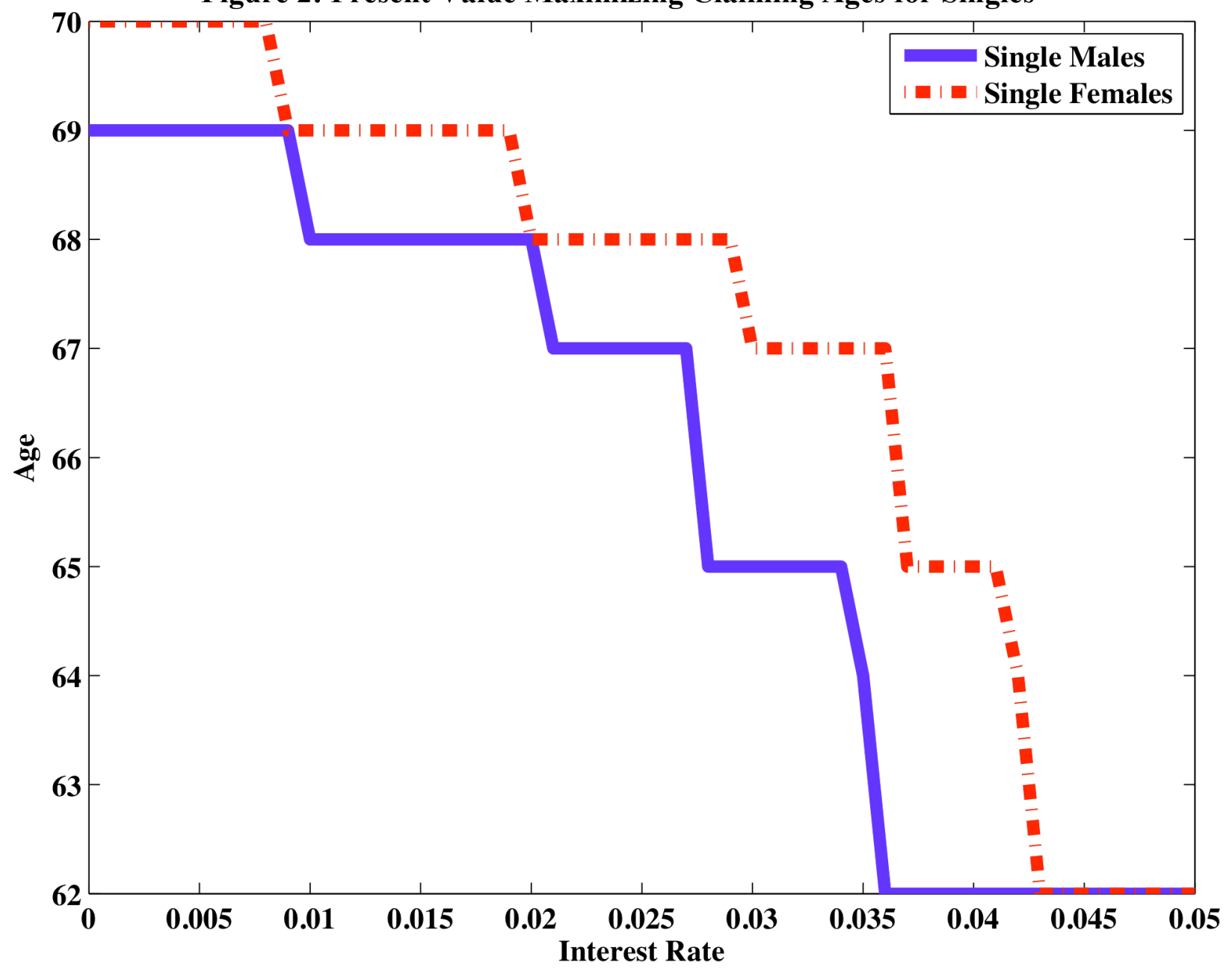

Notes: See notes for Figure 1. Claiming restricted to birthdates between ages 62 and 70. Present values are expected values computed over all possible realizations of age at death. 
Figure 3: Maximum Gain from Delay, Singles

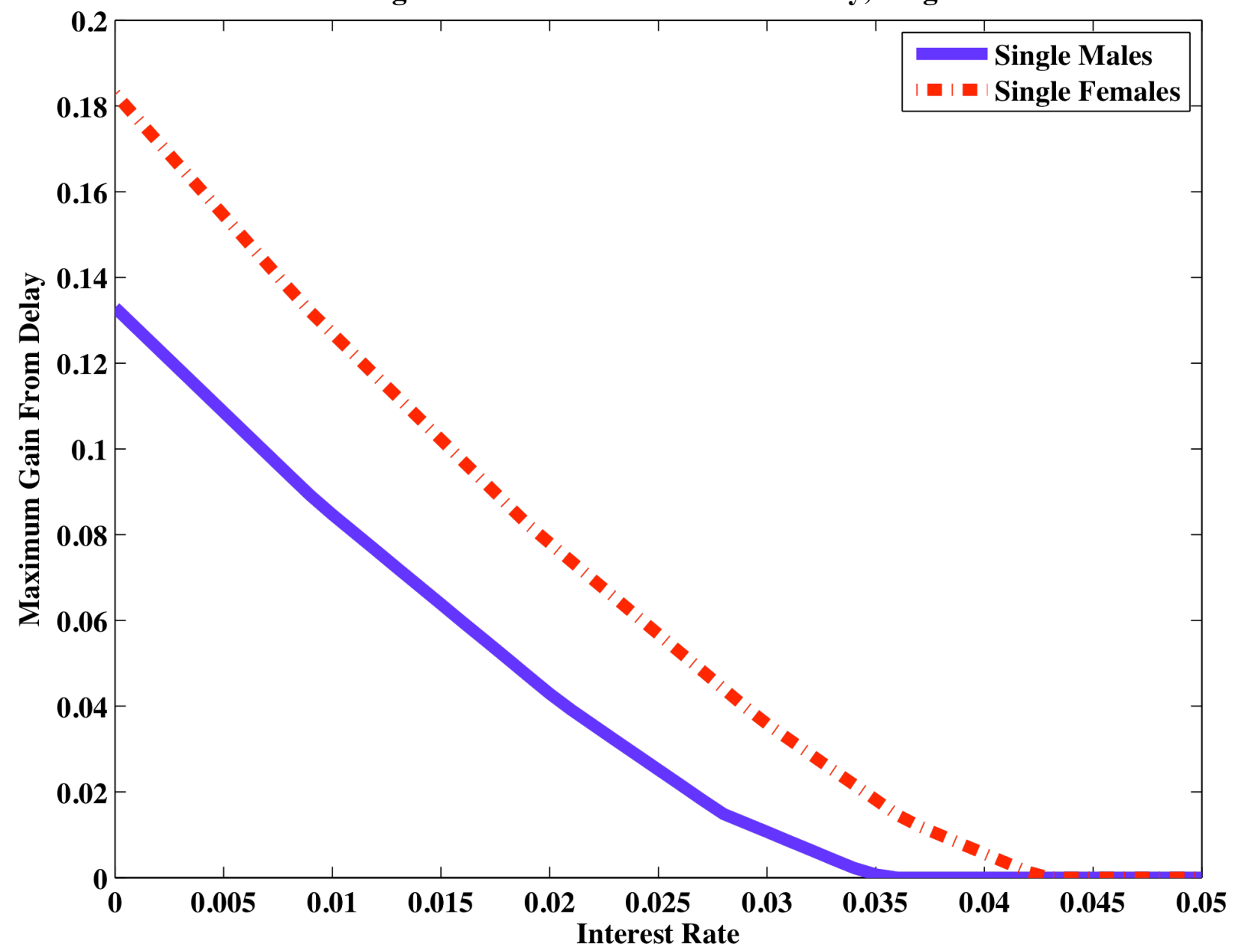

Notes: See notes for Figures 1 and 2. Vertical axis measures difference between maximum achievable present value and present value from claiming at age 62, as fraction of present value from claiming at age 62 . 
Figure 4: Gain from Additional Year of Delay, Singles
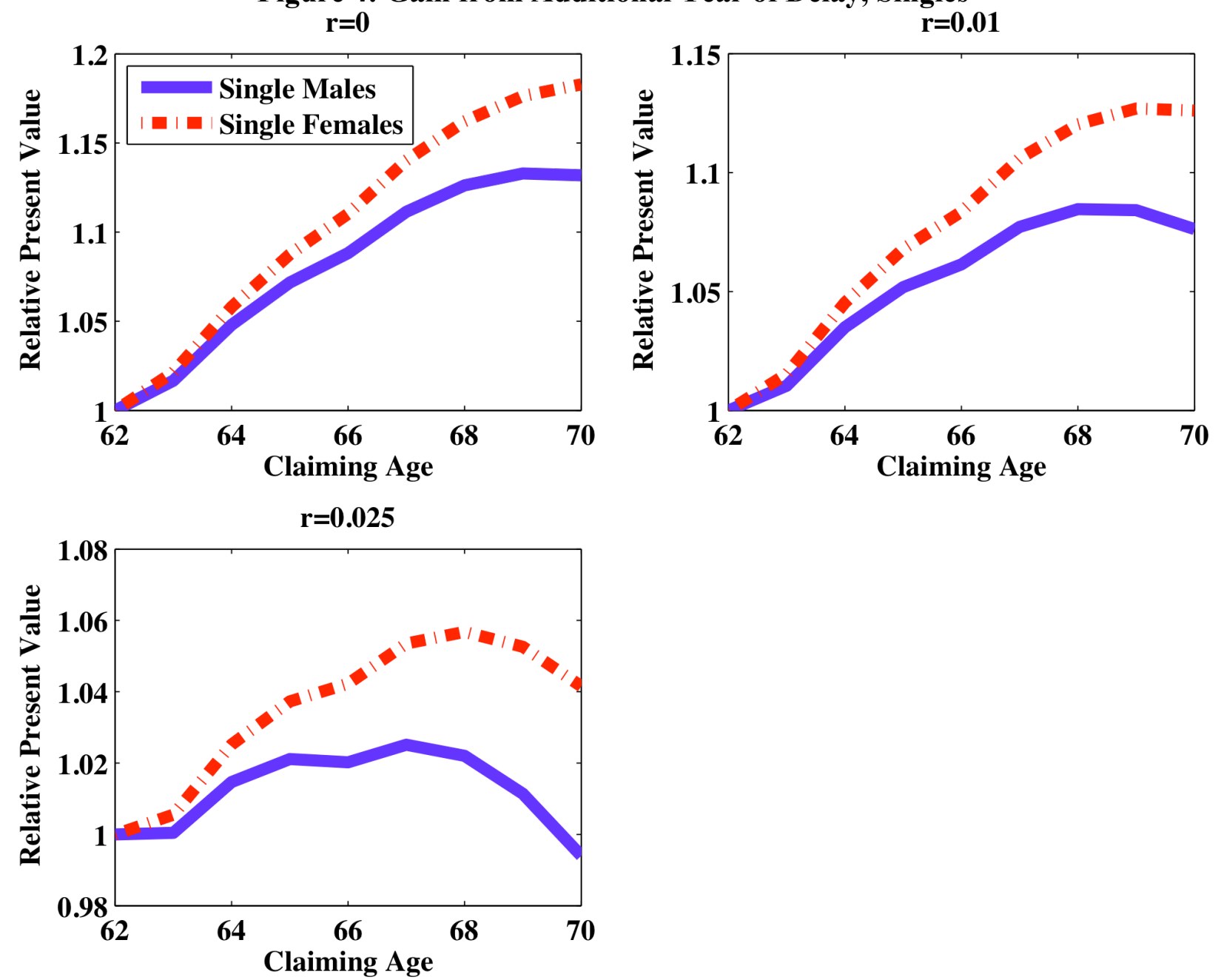

Notes: See notes for Figures 1 and 2. Vertical axis measures ratio of present value from claiming at specified age, as fraction of present value from claiming at age 62 . 
Figure 5: Present Value Maximizing Claiming Ages for Couples

Primary Earner

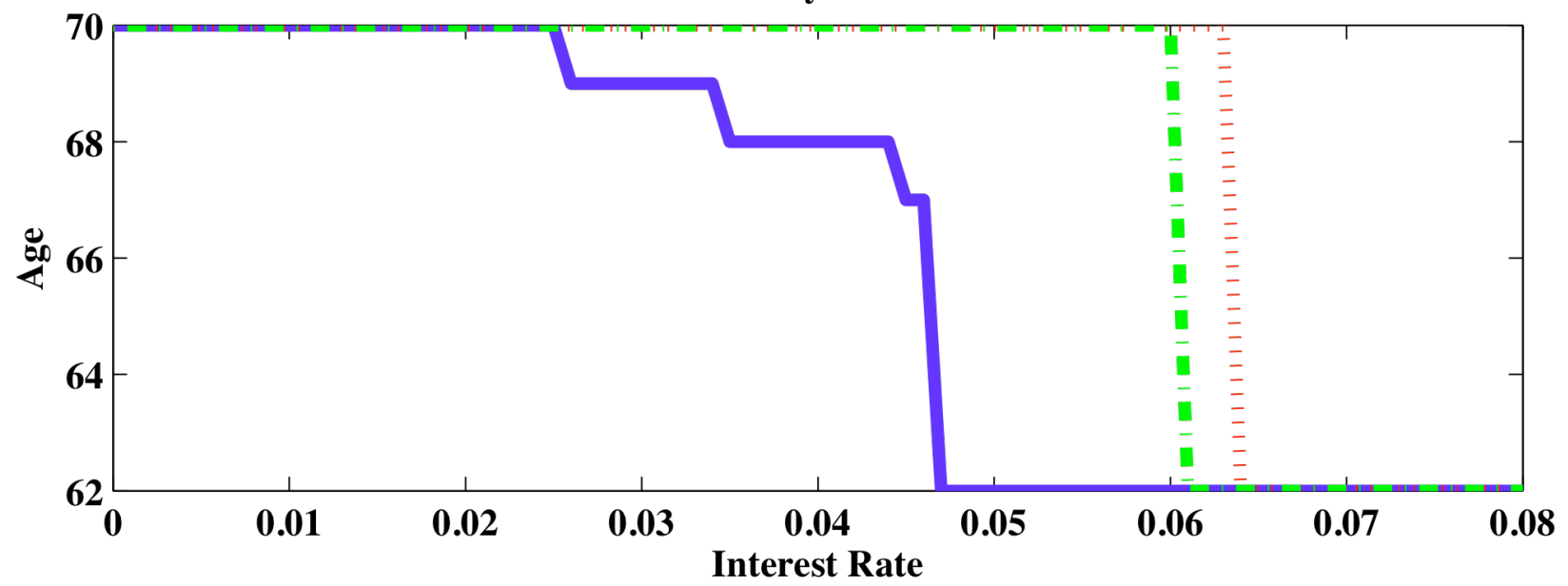

Secondary Earner

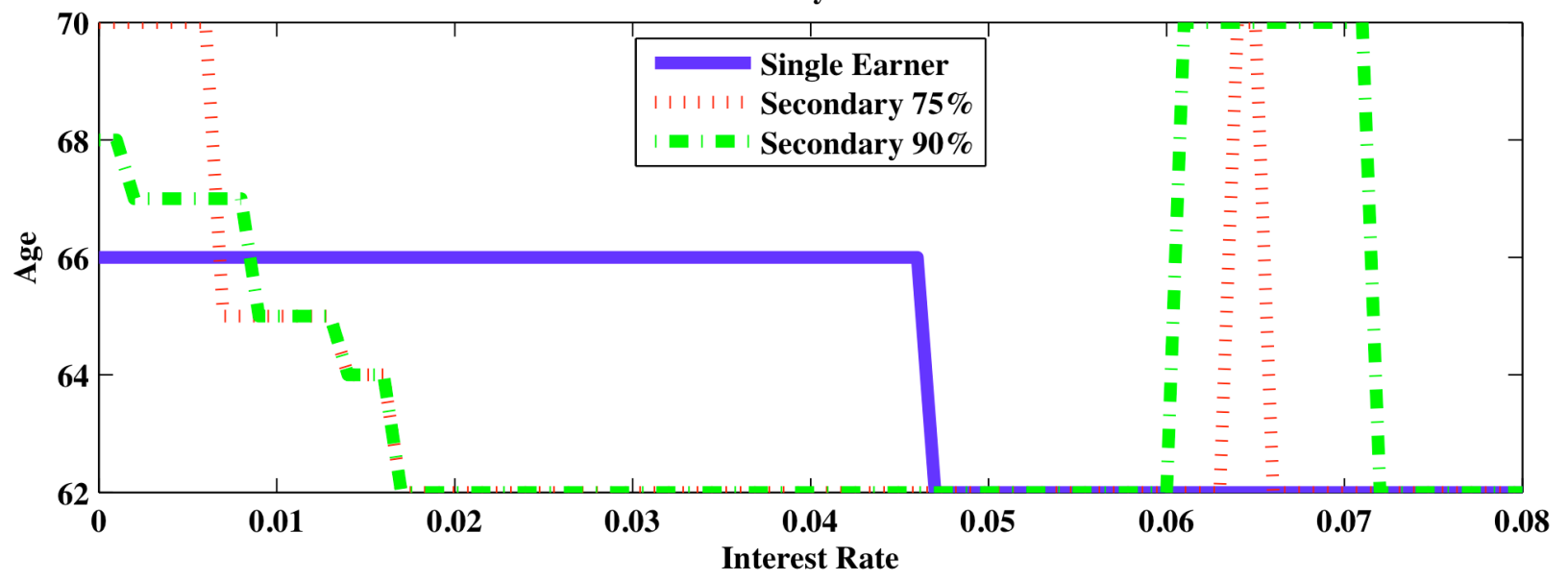

Notes: See notes for Figure 1. Claiming restricted to birthdates between ages 62 and 70. Present values are expected values computed over all possible realizations of age at death. Primary earner assumed to be male and secondary earner assumed to be female. 
Figure 6: Maximum Gain from Delay, Couples

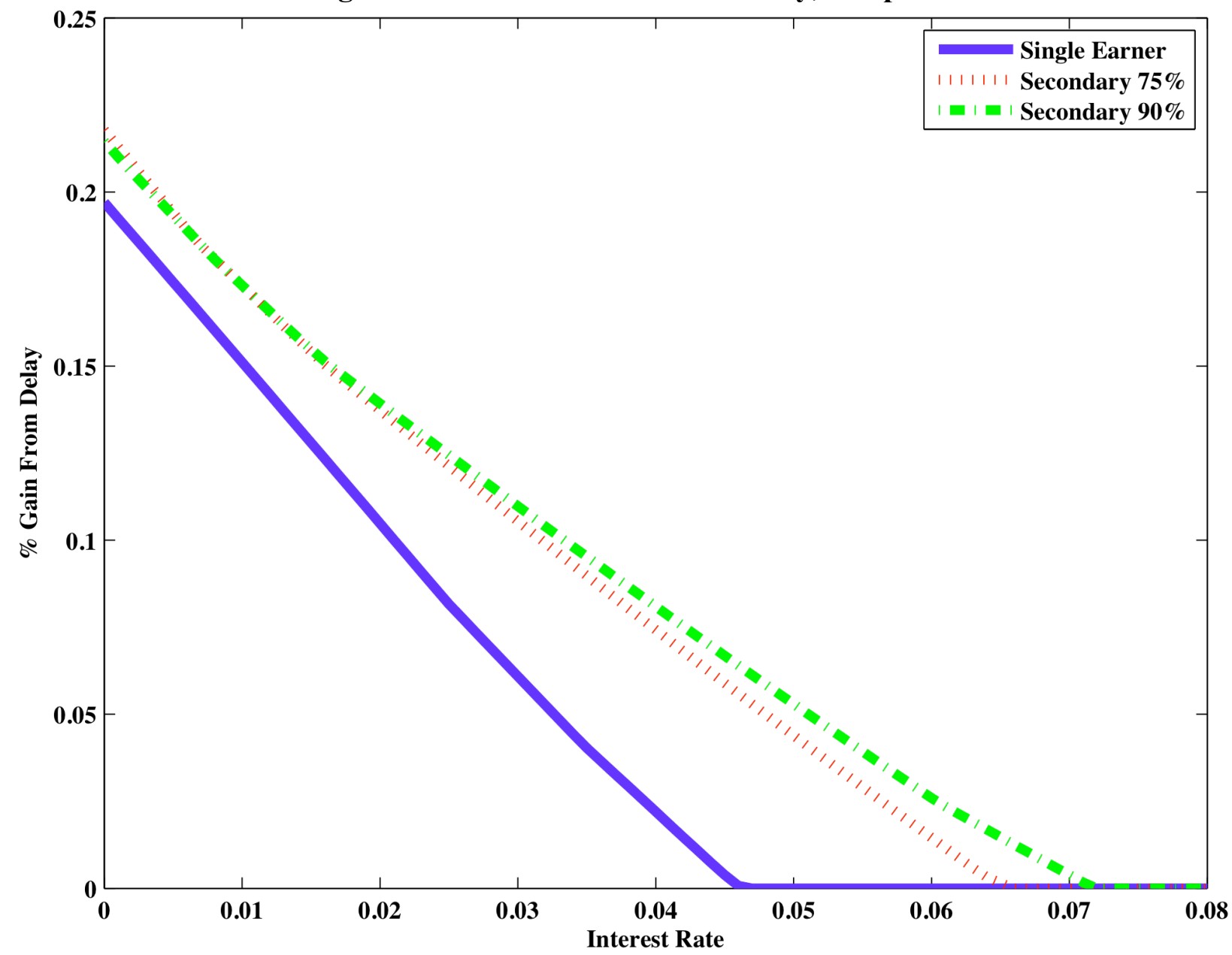

Notes: See notes for Figures 1 and 5. Vertical axis measures difference between maximum achievable present value and present value from claiming at age 62, as fraction of present value from claiming at age 62 . 
Figure 7: Gain from Additional Year of Delay, Couples
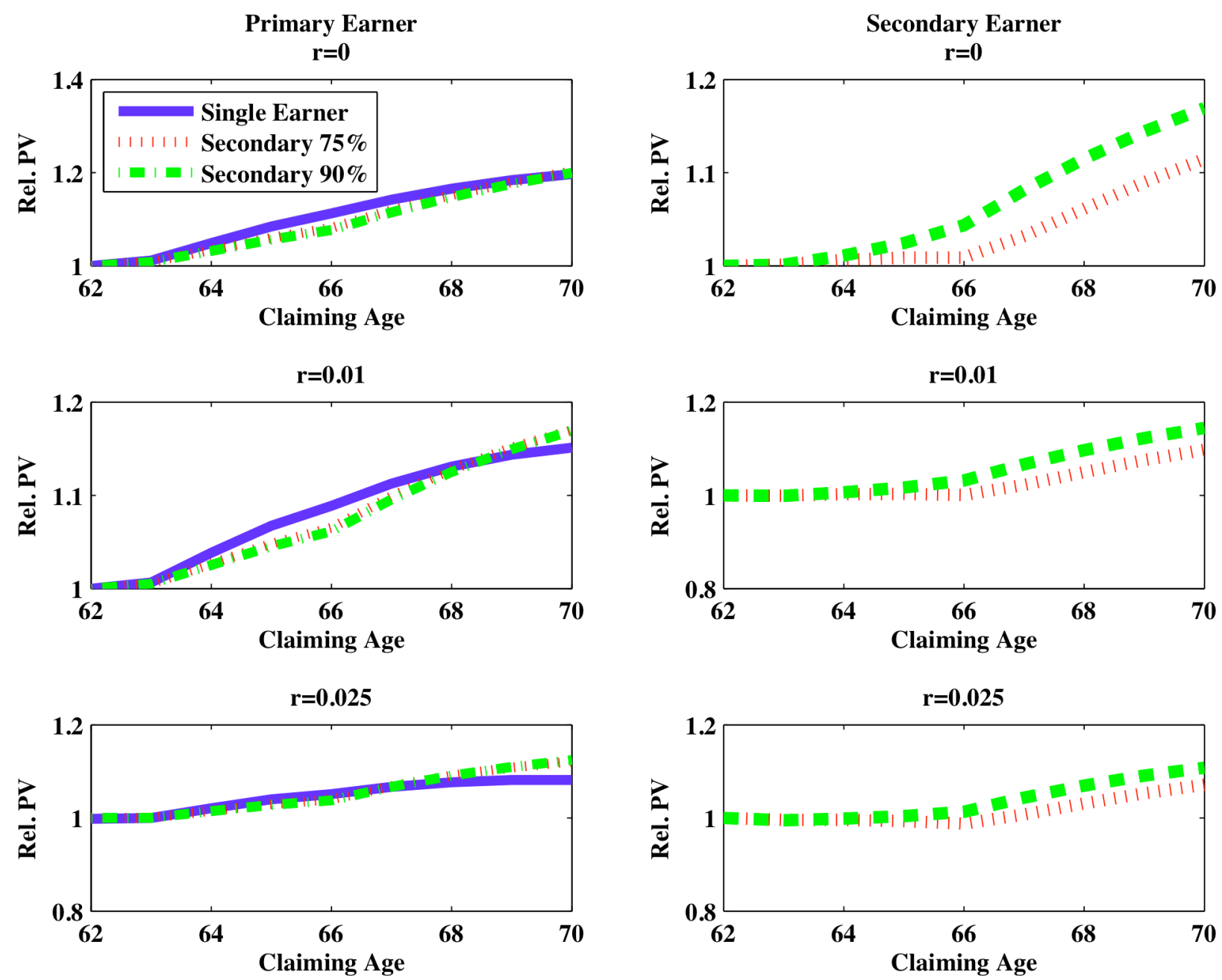

Notes: See notes for Figures 1 and 5. Vertical axis measures difference between maximum achievable present value and present value from claiming at age 62 , as fraction of present value from claiming at age 62 . Claiming age is for worker benefits for primary earners and secondary earners in two-earner households. For individuals in two-earner households, spouse assumed to claim worker benefits at age 62 , and individual is assumed to commence spousal benefits at age 66 when possible. For primary earner in one-earner household, secondary earner assumed to claim spousal benefits at earliest possible age (smaller of primary earner's claiming age and 66). 
Figure 8: Months Claiming Delay Since Age 62

(Full Sample)

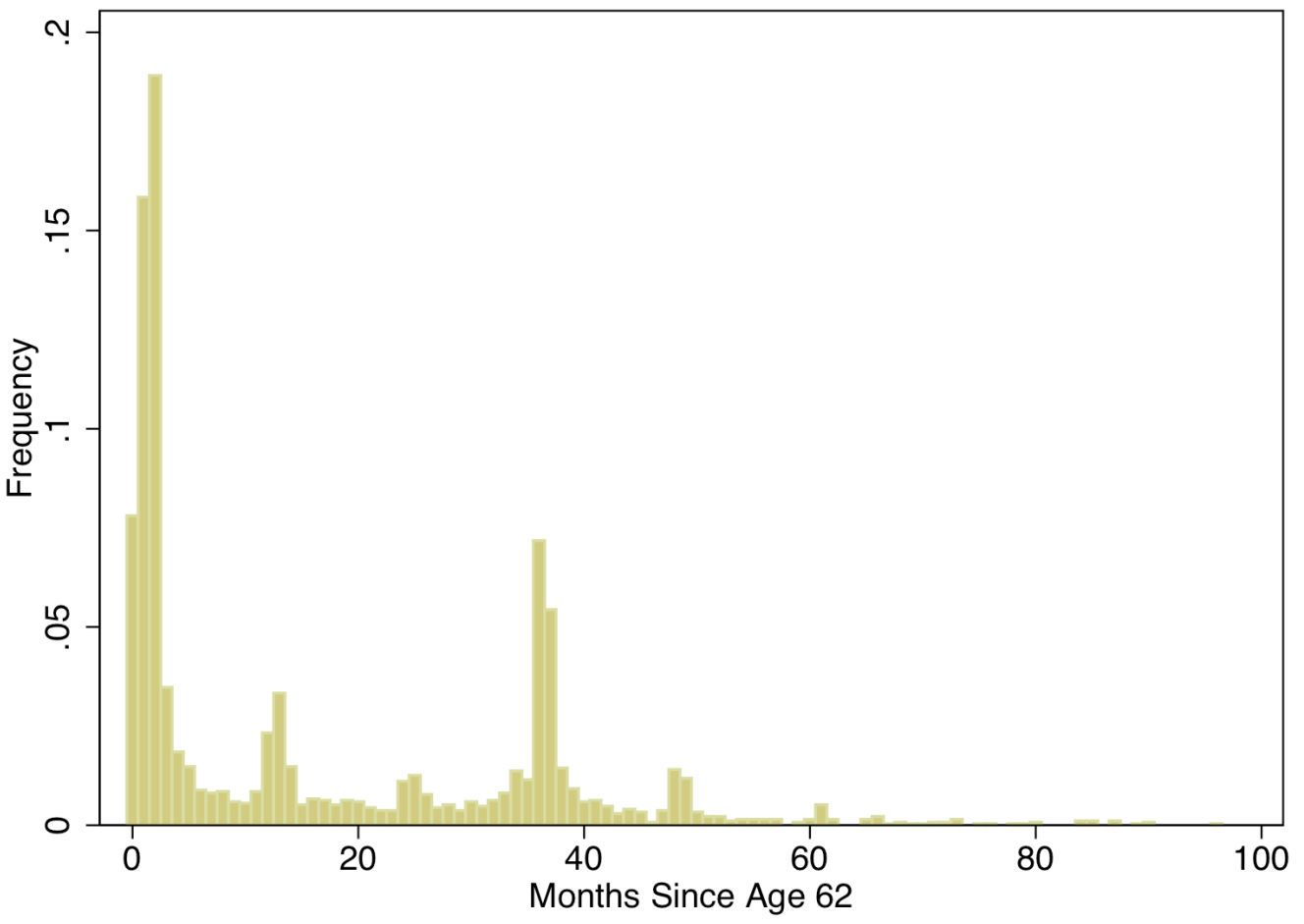

Figure 9: Months Claiming Delay Since Age 62

(Stopped Working by Age 62)

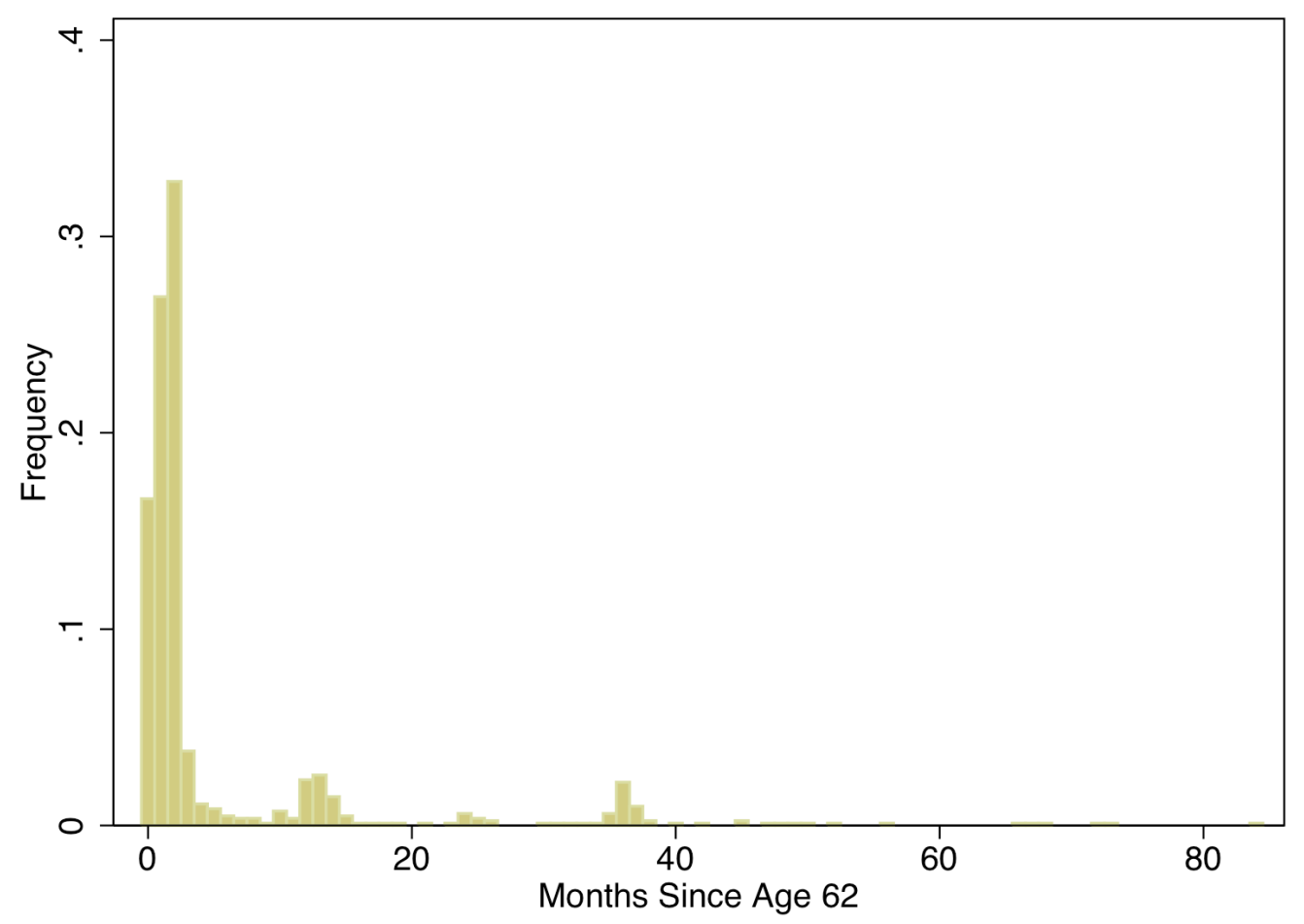


Figure 10: Months Claiming Delay Since Age 62

(Males)

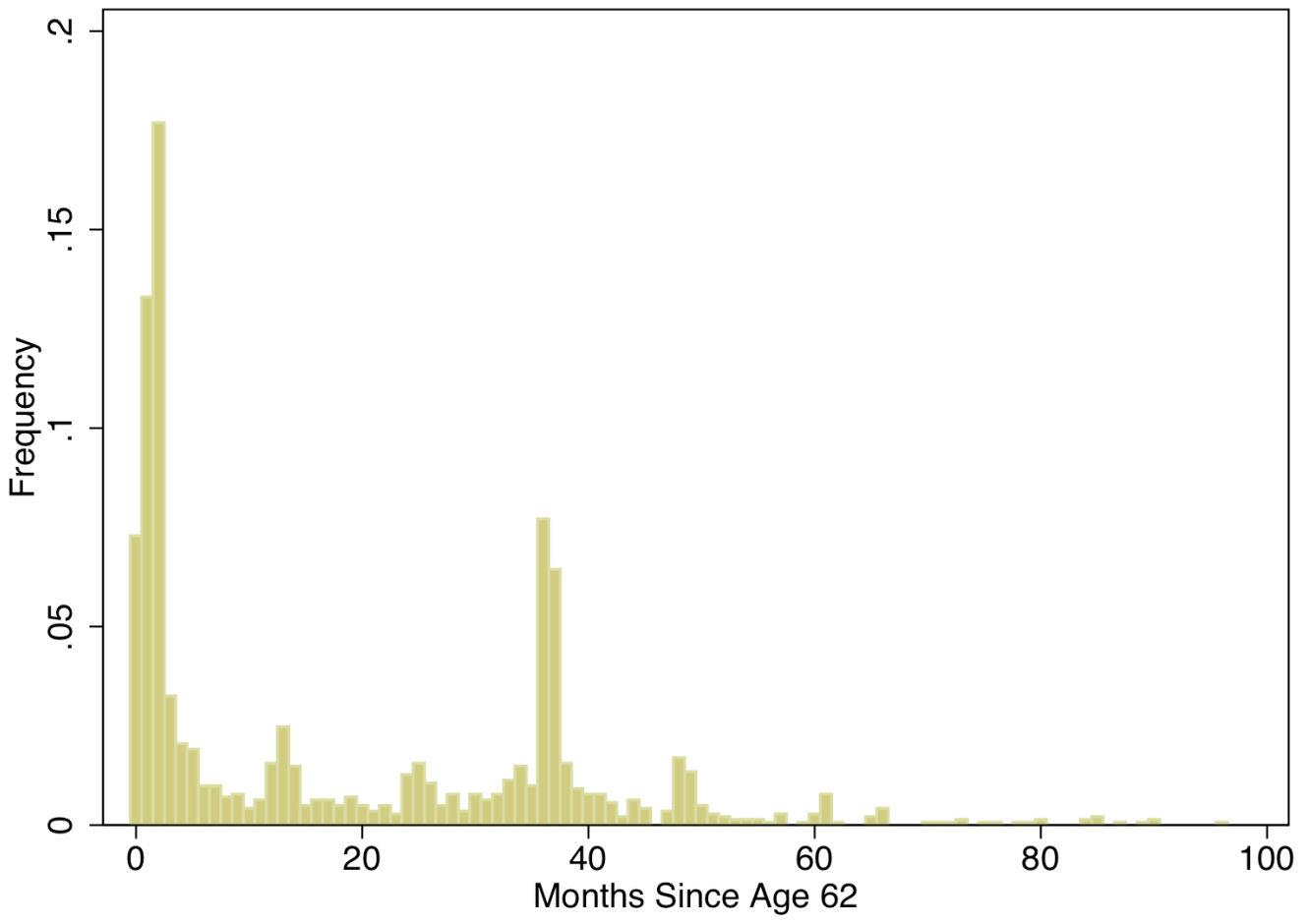

Figure 11: Months Claiming Delay Since Age 62 or Last Worked (Not Working at Claim)

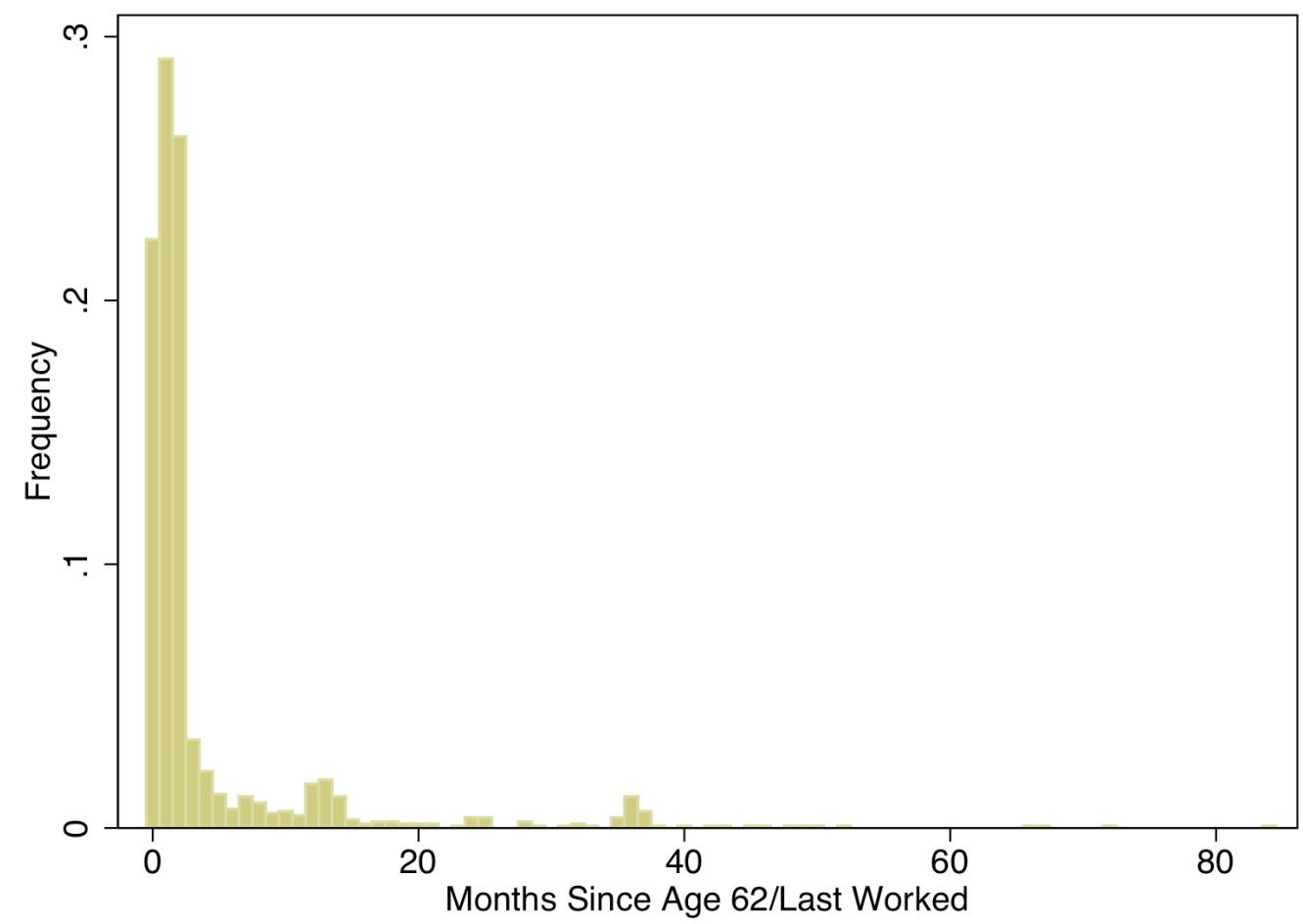


Table 1: Benefit Adjustment Formula

\begin{tabular}{ccccc}
\hline $\begin{array}{c}\text { Claiming } \\
\text { Age }\end{array}$ & $\begin{array}{c}\text { Own Benefit (\% } \\
\text { of PIA) }\end{array}$ & $\begin{array}{c}\text { Own Benefit: Percent } \\
\text { Increase from 1-Year } \\
\text { Delay }\end{array}$ & $\begin{array}{c}\text { Spousal Benefit (\% } \\
\text { of Primary PIA) }\end{array}$ & $\begin{array}{c}\text { Spousal Benefit: } \\
\text { Percent Increase } \\
\text { from 1-Year Delay }\end{array}$ \\
\hline 62 & $75.0 \%$ & & $35.0 \%$ & \\
63 & $80.0 \%$ & $6.7 \%$ & $37.5 \%$ & $7.1 \%$ \\
64 & $86.7 \%$ & $8.3 \%$ & $41.7 \%$ & $11.1 \%$ \\
65 & $93.3 \%$ & $7.7 \%$ & $45.8 \%$ & $10.0 \%$ \\
66 & $100.0 \%$ & $7.1 \%$ & $50.0 \%$ & $9.1 \%$ \\
67 & $108.0 \%$ & $8.0 \%$ & $50.0 \%$ & $0.0 \%$ \\
68 & $116.0 \%$ & $7.4 \%$ & $50.0 \%$ & $0.0 \%$ \\
69 & $124.0 \%$ & $6.9 \%$ & $50.0 \%$ & $0.0 \%$ \\
70 & $132.0 \%$ & $6.5 \%$ & $50.0 \%$ & $0.0 \%$ \\
\hline
\end{tabular}

Table 2: Widow Benefit as Percent of Deceased Spouse PIA

\begin{tabular}{|c|c|c|c|c|c|c|c|c|c|c|c|}
\hline \multicolumn{12}{|c|}{ Worker's Age at Death } \\
\hline \multirow{10}{*}{$\begin{array}{l}\text { Worker's } \\
\text { Intended } \\
\text { Claiming } \\
\text { Age }\end{array}$} & & 62.5 & 63.5 & 64.5 & 65.5 & 66.5 & 67.5 & 68.5 & 69.5 & $\overline{70.5}$ & Widow Limit \\
\hline & 62 & $82.5 \%$ & $82.5 \%$ & $82.5 \%$ & $82.5 \%$ & $82.5 \%$ & $82.5 \%$ & $82.5 \%$ & $82.5 \%$ & $82.5 \%$ & $82.5 \%$ \\
\hline & 63 & $83.4 \%$ & $82.5 \%$ & $82.5 \%$ & $82.5 \%$ & $82.5 \%$ & $82.5 \%$ & $82.5 \%$ & $82.5 \%$ & $82.5 \%$ & $82.5 \%$ \\
\hline & 64 & $83.4 \%$ & $88.1 \%$ & $86.7 \%$ & $86.7 \%$ & $86.7 \%$ & $86.7 \%$ & $86.7 \%$ & $86.7 \%$ & $86.7 \%$ & $86.7 \%$ \\
\hline & 65 & $83.4 \%$ & $88.1 \%$ & $92.9 \%$ & $93.3 \%$ & $93.3 \%$ & $93.3 \%$ & $93.3 \%$ & $93.3 \%$ & $93.3 \%$ & $93.3 \%$ \\
\hline & 66 & $83.4 \%$ & $88.1 \%$ & $92.9 \%$ & $97.6 \%$ & $100.0 \%$ & $100.0 \%$ & $100.0 \%$ & $100.0 \%$ & $100.0 \%$ & - \\
\hline & 67 & $83.4 \%$ & $88.1 \%$ & $92.9 \%$ & $97.6 \%$ & $104.0 \%$ & $108.0 \%$ & $108.0 \%$ & $108.0 \%$ & $108.0 \%$ & - \\
\hline & 68 & $83.4 \%$ & $88.1 \%$ & $92.9 \%$ & $97.6 \%$ & $104.0 \%$ & $112.0 \%$ & $116.0 \%$ & $116.0 \%$ & $116.0 \%$ & - \\
\hline & 69 & $83.4 \%$ & $88.1 \%$ & $92.9 \%$ & $97.6 \%$ & $104.0 \%$ & $112.0 \%$ & $120.0 \%$ & $124.0 \%$ & $124.0 \%$ & - \\
\hline & 70 & $83.4 \%$ & $88.1 \%$ & $92.9 \%$ & $97.6 \%$ & $104.0 \%$ & $112.0 \%$ & $120.0 \%$ & $128.0 \%$ & $132.0 \%$ & - \\
\hline
\end{tabular}

Notes: Gray cells indicate that worker died before claiming. White cells indicate that worker died after claiming. Widow limit applies if worker claimed before full retirement age. 
Table 3: Summary Statistics

\begin{tabular}{|c|c|c|c|c|}
\hline Variable & Mean & Std. Dev. & Minimum & Maximum \\
\hline Claimed 2 Months from 62 & 0.4256 & 0.4945 & 0 & 1 \\
\hline Claimed 2 Months from 62 or Last Worked & 0.5977 & 0.4905 & 0 & 1 \\
\hline Claimed at or After NRA & 0.2391 & 0.4266 & 0 & 1 \\
\hline Claiming Age (Months) & 760.4141 & 18.3241 & 744 & 840 \\
\hline Married Male $^{\mathrm{a}}$ & 0.4597 & 0.4985 & 0 & 1 \\
\hline Married Female $^{a}$ & 0.3764 & 0.4846 & 0 & 1 \\
\hline Single Male ${ }^{a}$ & 0.0633 & 0.2435 & 0 & 1 \\
\hline Single Female ${ }^{a}$ & 0.1007 & 0.3009 & 0 & 1 \\
\hline White & 0.8560 & 0.3511 & 0 & 1 \\
\hline African American & 0.1132 & 0.3170 & 0 & 1 \\
\hline Other Race & 0.0307 & 0.1726 & 0 & 1 \\
\hline Some College & 0.4164 & 0.4930 & 0 & 1 \\
\hline Interest Rate $^{\mathrm{b}}$ & 4.7611 & 0.8566 & 2.96 & 6.21 \\
\hline Unemployment Rate $^{\mathrm{b}}$ & 5.3385 & 0.9610 & 3.8 & 7.8 \\
\hline $\mathrm{P}($ Live to 75$) \leq 50 \%{ }^{\mathrm{a}}$ & 0.3357 & 0.4723 & 0 & 1 \\
\hline $\mathrm{P}($ Live to 75$)>50 \%^{\mathrm{a}}$ & 0.5688 & 0.4953 & 0 & 1 \\
\hline $\mathrm{P}($ Live to 75$)$ Missing $^{a}$ & 0.0955 & 0.2939 & 0 & 1 \\
\hline Long Planning Horizon $^{c}$ & 0.5903 & 0.4919 & 0 & 1 \\
\hline Short Planning Horizon $^{c}$ & 0.3864 & 0.4870 & 0 & 1 \\
\hline Planning Horizon Missing ${ }^{\mathfrak{c}}$ & 0.0233 & 0.1509 & 0 & 1 \\
\hline $\mathrm{P}($ Bequest $)<50 \%{ }^{\mathrm{a}}$ & 0.4645 & 0.4988 & 0 & 1 \\
\hline $\mathrm{P}($ Bequest $) \geq 50 \%^{\mathrm{a}}$ & 0.4626 & 0.4987 & 0 & 1 \\
\hline $\mathrm{P}($ Bequest $)$ Missing $^{\mathrm{a}}$ & 0.0729 & 0.2600 & 0 & 1 \\
\hline Financial Assets $^{\mathrm{a}}$ & 144119.6000 & 347385.3000 & -400000 & 7246000 \\
\hline Worked 35 Years $^{\mathrm{a}}$ & 0.6510 & 0.4767 & 0 & 1 \\
\hline Working $^{\mathrm{a}}$ & 0.7246 & 0.4468 & 0 & 1 \\
\hline $\mathrm{P}($ Work After 62$) \leq 50 \%{ }^{\mathrm{a}}$ & 0.3679 & 0.4823 & 0 & 1 \\
\hline $\mathrm{P}($ Work After 62$)>50 \%{ }^{\mathrm{a}}$ & 0.3386 & 0.4733 & 0 & 1 \\
\hline $\mathrm{P}\left(\right.$ Work After 62) Missing ${ }^{\mathrm{a}}$ & 0.2935 & 0.4554 & 0 & 1 \\
\hline Retired Before 62 & 0.3024 & 0.4594 & 0 & 1 \\
\hline Not Working at Claim & 0.4882 & 0.5000 & 0 & 1 \\
\hline
\end{tabular}

Notes: All statistics based on sample of 2,702 respondents.

a - Measured in most recent wave prior to turning 62 .

$\mathrm{b}$ - Measured in month of turning 62 .

c - Based on median of all available waves. 
Table 4: Determinants of Early Claiming

\begin{tabular}{|c|c|c|c|c|c|c|c|c|}
\hline & $(1)$ & $(2)$ & (3) & (4) & $(5)$ & $(6)$ & $(7)$ & $(8)$ \\
\hline Married Female & $\begin{array}{c}0.103 * * * \\
(0.0202)\end{array}$ & $\begin{array}{c}0.0270 \\
(0.0223)\end{array}$ & $\begin{array}{c}-0.155^{* * * *} \\
(0.0299)\end{array}$ & $\begin{array}{c}-0.0519 \\
(0.0386)\end{array}$ & $\begin{array}{c}-0.133 * * * \\
(0.0253)\end{array}$ & $\begin{array}{c}-0.0763 * * \\
(0.0308)\end{array}$ & & \\
\hline Single Male & $\begin{array}{c}0.0226 \\
(0.0399)\end{array}$ & $\begin{array}{c}0.0339 \\
(0.0359)\end{array}$ & $\begin{array}{l}-0.00340 \\
(0.0597)\end{array}$ & $\begin{array}{c}0.0231 \\
(0.0668)\end{array}$ & $\begin{array}{c}0.0270 \\
(0.0435)\end{array}$ & $\begin{array}{c}0.0402 \\
(0.0465)\end{array}$ & $\begin{array}{c}0.0195 \\
(0.0404)\end{array}$ & $\begin{array}{c}0.0330 \\
(0.0354)\end{array}$ \\
\hline Single Female & $\begin{array}{l}0.00912 \\
(0.0335)\end{array}$ & $\begin{array}{c}0.0265 \\
(0.0322)\end{array}$ & $\begin{array}{c}-0.0166 \\
(0.0545)\end{array}$ & $\begin{array}{c}0.0474 \\
(0.0570)\end{array}$ & $\begin{array}{c}0.0110 \\
(0.0382)\end{array}$ & $\begin{array}{c}0.0487 \\
(0.0382)\end{array}$ & & \\
\hline African American & $\begin{array}{c}-0.0264 \\
(0.0318)\end{array}$ & $\begin{array}{c}-0.0530 * \\
(0.0288)\end{array}$ & $\begin{array}{c}-0.0663 \\
(0.0543)\end{array}$ & $\begin{array}{c}-0.0861 \\
(0.0546)\end{array}$ & $\begin{array}{l}-0.0587 \\
(0.0403)\end{array}$ & $\begin{array}{c}-0.0660 \\
(0.0406)\end{array}$ & $\begin{array}{c}-0.0191 \\
(0.0442)\end{array}$ & $\begin{array}{r}-0.0410 \\
(0.0376)\end{array}$ \\
\hline Other Race & $\begin{array}{c}0.0119 \\
(0.0556)\end{array}$ & $\begin{array}{l}-0.0432 \\
(0.0490)\end{array}$ & $\begin{array}{c}0.0415 \\
(0.0699)\end{array}$ & $\begin{array}{c}0.0451 \\
(0.0656)\end{array}$ & $\begin{array}{l}-0.0477 \\
(0.0647)\end{array}$ & $\begin{array}{c}-0.0460 \\
(0.0631)\end{array}$ & $\begin{array}{c}-0.0482 \\
(0.0771)\end{array}$ & $\begin{array}{c}-0.0933 \\
(0.0603)\end{array}$ \\
\hline Some College & $\begin{array}{c}-0.108 * * * \\
(0.0207)\end{array}$ & $\begin{array}{c}-0.0674 * * * \\
(0.0190)\end{array}$ & $\begin{array}{l}-0.0330 \\
(0.0332)\end{array}$ & $\begin{array}{c}-0.0402 \\
(0.0334)\end{array}$ & $\begin{array}{l}-0.0504 * \\
(0.0258)\end{array}$ & $\begin{array}{c}-0.0474 * \\
(0.0256)\end{array}$ & $\begin{array}{c}-0.0942 * * * \\
(0.0275)\end{array}$ & $\begin{array}{c}-0.0658 * * * \\
(0.0243)\end{array}$ \\
\hline Interest Rate & $\begin{array}{c}-0.00508 \\
(0.0147)\end{array}$ & $\begin{array}{c}-0.0107 \\
(0.0136)\end{array}$ & $\begin{array}{c}-0.0254 \\
(0.0223)\end{array}$ & $\begin{array}{c}-0.0337 \\
(0.0240)\end{array}$ & $\begin{array}{l}-0.0246 \\
(0.0176)\end{array}$ & $\begin{array}{c}-0.0251 \\
(0.0180)\end{array}$ & $\begin{array}{l}-0.00976 \\
(0.0204)\end{array}$ & $\begin{array}{r}-0.00996 \\
(0.0176)\end{array}$ \\
\hline Unemployment Rate & $\begin{array}{c}0.0213 \\
(0.0132)\end{array}$ & $\begin{array}{c}0.0166 \\
(0.0122)\end{array}$ & $\begin{array}{c}0.0226 \\
(0.0198)\end{array}$ & $\begin{array}{c}0.0209 \\
(0.0208)\end{array}$ & $\begin{array}{c}0.0103 \\
(0.0159)\end{array}$ & $\begin{array}{c}0.0150 \\
(0.0162)\end{array}$ & $\begin{array}{c}0.0108 \\
(0.0184)\end{array}$ & $\begin{array}{c}0.0124 \\
(0.0156)\end{array}$ \\
\hline Long Planning Horizon & $\begin{array}{c}-0.0221 \\
(0.0202)\end{array}$ & $\begin{array}{c}-0.0230 \\
(0.0185)\end{array}$ & $\begin{array}{l}-0.0181 \\
(0.0313)\end{array}$ & $\begin{array}{c}-0.0177 \\
(0.0310)\end{array}$ & $\begin{array}{c}0.0232 \\
(0.0243)\end{array}$ & $\begin{array}{c}0.0259 \\
(0.0241)\end{array}$ & $\begin{array}{l}-0.00927 \\
(0.0273)\end{array}$ & $\begin{array}{c}-0.0184 \\
(0.0238)\end{array}$ \\
\hline Planning Horizon Missing & $\begin{array}{c}0.0196 \\
(0.0694)\end{array}$ & $\begin{array}{c}-0.0134 \\
(0.0606)\end{array}$ & $\begin{array}{l}-0.0235 \\
(0.101)\end{array}$ & $\begin{array}{r}0.00719 \\
(0.0964)\end{array}$ & $\begin{array}{c}-0.122 \\
(0.0940)\end{array}$ & $\begin{array}{c}-0.102 \\
(0.0934)\end{array}$ & $\begin{array}{c}0.0144 \\
(0.0784)\end{array}$ & $\begin{array}{c}-0.0361 \\
(0.0649)\end{array}$ \\
\hline $\mathrm{P}($ Bequest $) \geq 50 \%$ & $\begin{array}{l}-0.00400 \\
(0.0210)\end{array}$ & $\begin{array}{c}0.00927 \\
(0.0191)\end{array}$ & $\begin{array}{l}-0.0557^{*} \\
(0.0315)\end{array}$ & $\begin{array}{c}-0.0564 * \\
(0.0313)\end{array}$ & $\begin{array}{l}-0.0224 \\
(0.0249)\end{array}$ & $\begin{array}{c}-0.0156 \\
(0.0250)\end{array}$ & $\begin{array}{c}0.0194 \\
(0.0287)\end{array}$ & $\begin{array}{c}0.0206 \\
(0.0251)\end{array}$ \\
\hline $\mathrm{P}$ (Bequest) Missing & $\begin{array}{l}-0.0258 \\
(0.0514)\end{array}$ & $\begin{array}{l}-0.0290 \\
(0.0504)\end{array}$ & $\begin{array}{c}-0.133 \\
(0.0928)\end{array}$ & $\begin{array}{c}-0.111 \\
(0.0891)\end{array}$ & $\begin{array}{l}-0.0179 \\
(0.0628)\end{array}$ & $\begin{array}{c}-0.0110 \\
(0.0623)\end{array}$ & $\begin{array}{c}-0.0893 \\
(0.0628)\end{array}$ & $\begin{array}{l}-0.123 * * \\
(0.0617)\end{array}$ \\
\hline $\mathrm{P}($ Live to 75$)>50 \%$ & $\begin{array}{c}-0.0359 * \\
(0.0208)\end{array}$ & $\begin{array}{r}-0.00817 \\
(0.0188)\end{array}$ & $\begin{array}{c}-0.0266 \\
(0.0313)\end{array}$ & $\begin{array}{c}-0.0134 \\
(0.0310)\end{array}$ & $\begin{array}{l}-0.0256 \\
(0.0250)\end{array}$ & $\begin{array}{c}-0.0129 \\
(0.0249)\end{array}$ & $\begin{array}{c}-0.0301 \\
(0.0283)\end{array}$ & $\begin{array}{c}0.0247 \\
(0.0244)\end{array}$ \\
\hline $\mathrm{P}($ Live to 75$)$ Missing & $\begin{array}{c}-0.0227 \\
(0.0482)\end{array}$ & $\begin{array}{c}0.0119 \\
(0.0454)\end{array}$ & $\begin{array}{c}0.0148 \\
(0.0685)\end{array}$ & $\begin{array}{c}0.0342 \\
(0.0665)\end{array}$ & $\begin{array}{c}0.0230 \\
(0.0539)\end{array}$ & $\begin{array}{c}0.0277 \\
(0.0544)\end{array}$ & $\begin{array}{c}0.0767 \\
(0.0666)\end{array}$ & $\begin{array}{c}0.132 * * \\
(0.0580)\end{array}$ \\
\hline Assets Quintile 2 & $\begin{array}{r}-0.00109 \\
(0.0296)\end{array}$ & $\begin{array}{c}0.000771 \\
(0.0283)\end{array}$ & $\begin{array}{c}0.0769 \\
(0.0569)\end{array}$ & $\begin{array}{c}0.0555 \\
(0.0549)\end{array}$ & $\begin{array}{l}0.0771 * \\
(0.0415)\end{array}$ & $\begin{array}{c}0.0613 \\
(0.0402)\end{array}$ & $\begin{array}{r}-0.0159 \\
(0.0406)\end{array}$ & $\begin{array}{r}-0.00219 \\
(0.0373)\end{array}$ \\
\hline Assets Quintile 3 & $\begin{array}{c}0.0405 \\
(0.0307)\end{array}$ & $\begin{array}{c}0.0303 \\
(0.0294)\end{array}$ & $\begin{array}{l}0.110 * * \\
(0.0554)\end{array}$ & $\begin{array}{c}0.0667 \\
(0.0545)\end{array}$ & $\begin{array}{l}0.122 * * * \\
(0.0398)\end{array}$ & $\begin{array}{c}0.0946 * * \\
(0.0395)\end{array}$ & $\begin{array}{c}0.0415 \\
(0.0414)\end{array}$ & $\begin{array}{c}0.00189 \\
(0.0374)\end{array}$ \\
\hline Assets Quintile 4 & $\begin{array}{c}0.104 * * * \\
(0.0320)\end{array}$ & $\begin{array}{c}0.0567^{*} \\
(0.0301)\end{array}$ & $\begin{array}{l}0.173 * * * \\
(0.0517)\end{array}$ & $\begin{array}{c}0.140 * * * \\
(0.0504)\end{array}$ & $\begin{array}{l}0.105 * * \\
(0.0415)\end{array}$ & $\begin{array}{c}0.0715^{*} \\
(0.0415)\end{array}$ & $\begin{array}{c}0.0503 \\
(0.0431)\end{array}$ & $\begin{array}{c}0.00376 \\
(0.0387)\end{array}$ \\
\hline Assets Quintile 5 & $\begin{array}{c}0.110 * * * \\
(0.0344)\end{array}$ & $\begin{array}{c}0.0231 \\
(0.0318)\end{array}$ & $\begin{array}{c}0.166^{* * *} * \\
(0.0536)\end{array}$ & $\begin{array}{c}0.145^{* * *} * \\
(0.0524)\end{array}$ & $\begin{array}{l}0.105 * * \\
(0.0427)\end{array}$ & $\begin{array}{c}0.0771 * \\
(0.0428)\end{array}$ & $\begin{array}{l}0.0895 * * \\
(0.0455)\end{array}$ & $\begin{array}{c}0.00931 \\
(0.0405)\end{array}$ \\
\hline Worked 35 Years & & $\begin{array}{c}0.0451 * * \\
(0.0219)\end{array}$ & & $\begin{array}{c}0.156^{* * *} \\
(0.0363)\end{array}$ & & $\begin{array}{c}0.0975 * * * \\
(0.0292)\end{array}$ & & $\begin{array}{c}0.0805 * * \\
(0.0359)\end{array}$ \\
\hline Working & & $\begin{array}{c}-0.327 * * * \\
(0.0389)\end{array}$ & & $\begin{array}{c}0.00804 \\
(0.0545)\end{array}$ & & $\begin{array}{c}0.0119 \\
(0.0419)\end{array}$ & & $\begin{array}{c}-0.410 * * * \\
(0.0600)\end{array}$ \\
\hline $\mathrm{P}($ Work After 62$)>50 \%$ & & $\begin{array}{c}-0.278 * * * \\
(0.0220)\end{array}$ & & $\begin{array}{c}0.0373 \\
(0.0598)\end{array}$ & & $\begin{array}{c}-0.0973 * * * \\
(0.0358)\end{array}$ & & $\begin{array}{c}-0.290 * * * \\
(0.0273)\end{array}$ \\
\hline $\mathrm{P}($ Work After 62) Missing & & $\begin{array}{c}-0.0979 * * \\
(0.0413) \\
\end{array}$ & & $\begin{array}{c}-0.0657 \\
(0.0476) \\
\end{array}$ & & $\begin{array}{r}-0.0335 \\
(0.0403) \\
\end{array}$ & & $\begin{array}{c}-0.0423 \\
(0.0700) \\
\end{array}$ \\
\hline $\begin{array}{l}\text { Mean of Dep. Var. } \\
\text { Sample } \\
\text { Early Claim Def'n } \\
\text { Observations }\end{array}$ & \multicolumn{2}{|c|}{$\begin{array}{c}0.4256 \\
\text { All } \\
62 \\
2,702 \\
\end{array}$} & \multicolumn{2}{|c|}{0.7638} & \multicolumn{2}{|c|}{\begin{tabular}{|c|}
0.7665 \\
Not Working at Claim \\
62 or Last Worked \\
1,319
\end{tabular}} & \multicolumn{2}{|c|}{$\begin{array}{c}0.3829 \\
\text { Males } \\
62 \\
1,313 \\
\end{array}$} \\
\hline
\end{tabular}

Coefficients are average marginal effects from probit model. Standard errors (clustered by household) in parentheses. $* * * \mathrm{p}<0.01, * * \mathrm{p}<0.05, * \mathrm{p}<0.1$ 
Table 5: Determinants of Delayed Claiming

\begin{tabular}{|c|c|c|c|c|c|c|c|c|}
\hline & (1) & (2) & (3) & (4) & (5) & $(6)$ & (7) & $(8)$ \\
\hline Married Female & $\begin{array}{c}-0.0933 * * * \\
(0.0168)\end{array}$ & $\begin{array}{c}-0.0479 * * \\
(0.0197)\end{array}$ & $\begin{array}{l}0.0339 * * \\
(0.0139)\end{array}$ & $\begin{array}{c}-0.00834 \\
(0.0240)\end{array}$ & $\begin{array}{l}-0.0327^{*} \\
(0.0197)\end{array}$ & $\begin{array}{c}0.000277 \\
(0.0237)\end{array}$ & & \\
\hline Single Male & $\begin{array}{c}0.0206 \\
(0.0372)\end{array}$ & $\begin{array}{l}0.00223 \\
(0.0325)\end{array}$ & $\begin{array}{c}0.0390 \\
(0.0409)\end{array}$ & $\begin{array}{c}0.0378 \\
(0.0508)\end{array}$ & $\begin{array}{l}-0.0299 \\
(0.0397)\end{array}$ & $\begin{array}{c}-0.0198 \\
(0.0380)\end{array}$ & $\begin{array}{c}0.0198 \\
(0.0381)\end{array}$ & $\begin{array}{r}-0.00213 \\
(0.0341)\end{array}$ \\
\hline Single Female & $\begin{array}{c}0.0479 \\
(0.0316)\end{array}$ & $\begin{array}{c}0.0267 \\
(0.0295)\end{array}$ & $\begin{array}{c}0.0212 \\
(0.0298)\end{array}$ & $\begin{array}{r}-0.00742 \\
(0.0350)\end{array}$ & $\begin{array}{c}0.0505 \\
(0.0411)\end{array}$ & $\begin{array}{c}0.0348 \\
(0.0377)\end{array}$ & & \\
\hline African American & $\begin{array}{l}-0.0114 \\
(0.0267)\end{array}$ & $\begin{array}{c}0.0112 \\
(0.0262)\end{array}$ & $\begin{array}{l}-0.00733 \\
(0.0235)\end{array}$ & $\begin{array}{l}0.00480 \\
(0.0269)\end{array}$ & $\begin{array}{l}-0.0311 \\
(0.0267)\end{array}$ & $\begin{array}{c}-0.0193 \\
(0.0273)\end{array}$ & $\begin{array}{c}0.0269 \\
(0.0425)\end{array}$ & $\begin{array}{c}0.0435 \\
(0.0400)\end{array}$ \\
\hline Other Race & $\begin{array}{c}0.0167 \\
(0.0473)\end{array}$ & $\begin{array}{c}0.0510 \\
(0.0481)\end{array}$ & $\begin{array}{c}0.0103 \\
(0.0423)\end{array}$ & $\begin{array}{l}0.00622 \\
(0.0382)\end{array}$ & $\begin{array}{c}0.0237 \\
(0.0526)\end{array}$ & $\begin{array}{c}0.0367 \\
(0.0536)\end{array}$ & $\begin{array}{l}-0.0468 \\
(0.0662)\end{array}$ & $\begin{array}{l}-0.0135 \\
(0.0690)\end{array}$ \\
\hline Some College & $\begin{array}{c}0.101 * * * \\
(0.0182)\end{array}$ & $\begin{array}{c}0.0706^{* * *} \\
(0.0170)\end{array}$ & $\begin{array}{l}0.0471 * * \\
(0.0189)\end{array}$ & $\begin{array}{c}0.0494 * * \\
(0.0192)\end{array}$ & $\begin{array}{c}0.0556^{* * *} \\
(0.0215)\end{array}$ & $\begin{array}{l}0.0390^{*} \\
(0.0202)\end{array}$ & $\begin{array}{l}0.126^{* * *} \\
(0.0252)\end{array}$ & $\begin{array}{c}0.102 * * * \\
(0.0237)\end{array}$ \\
\hline Interest Rate & $\begin{array}{l}-0.0110 \\
(0.0126)\end{array}$ & $\begin{array}{l}-0.0108 \\
(0.0120)\end{array}$ & $\begin{array}{l}-0.00814 \\
(0.0113)\end{array}$ & $\begin{array}{l}-0.0138 \\
(0.0135)\end{array}$ & $\begin{array}{l}-0.00317 \\
(0.0145)\end{array}$ & $\begin{array}{r}-0.00359 \\
(0.0145)\end{array}$ & $\begin{array}{l}-0.00905 \\
(0.0191)\end{array}$ & $\begin{array}{r}-0.00982 \\
(0.0175)\end{array}$ \\
\hline Unemployment Rate & $\begin{array}{l}0.00317 \\
(0.0114)\end{array}$ & $\begin{array}{c}0.000754 \\
(0.0109)\end{array}$ & $\begin{array}{l}-0.0140 \\
(0.0101)\end{array}$ & $\begin{array}{c}-0.0188 * \\
(0.0112)\end{array}$ & $\begin{array}{c}0.0154 \\
(0.0137)\end{array}$ & $\begin{array}{c}0.00483 \\
(0.0134)\end{array}$ & $\begin{array}{c}0.0203 \\
(0.0172)\end{array}$ & $\begin{array}{c}0.0168 \\
(0.0156)\end{array}$ \\
\hline Long Planning Horizon & $\begin{array}{c}0.0171 \\
(0.0172)\end{array}$ & $\begin{array}{c}0.0171 \\
(0.0161)\end{array}$ & $\begin{array}{l}0.00391 \\
(0.0152)\end{array}$ & $\begin{array}{l}0.00685 \\
(0.0153)\end{array}$ & $\begin{array}{l}-0.00671 \\
(0.0193)\end{array}$ & $\begin{array}{r}-0.00792 \\
(0.0183)\end{array}$ & $\begin{array}{c}0.0177 \\
(0.0247)\end{array}$ & $\begin{array}{c}0.0198 \\
(0.0231)\end{array}$ \\
\hline Planning Horizo & $\begin{array}{c}0.0643 \\
(0.0625)\end{array}$ & $\begin{array}{c}0.0852 \\
(0.0584)\end{array}$ & $\begin{array}{c}0.0109 \\
(0.0566)\end{array}$ & $\begin{array}{r}-0.00309 \\
(0.0429)\end{array}$ & $\begin{array}{c}0.0965 \\
(0.0812)\end{array}$ & $\begin{array}{c}0.111 \\
(0.0766)\end{array}$ & $\begin{array}{c}0.0485 \\
(0.0751)\end{array}$ & $\begin{array}{c}0.0621 \\
(0.0684)\end{array}$ \\
\hline $\mathrm{P}($ Bequest $) \geq 50 \%$ & $\begin{array}{l}-0.00190 \\
(0.0180)\end{array}$ & $\begin{array}{l}-0.0109 \\
(0.0169)\end{array}$ & $\begin{array}{l}0.00201 \\
(0.0173)\end{array}$ & $\begin{array}{l}0.00227 \\
(0.0175)\end{array}$ & $\begin{array}{l}-0.00831 \\
(0.0201)\end{array}$ & $\begin{array}{c}-0.0217 \\
(0.0192)\end{array}$ & $\begin{array}{l}0.00464 \\
(0.0256)\end{array}$ & $\begin{array}{c}-0.000110 \\
(0.0234)\end{array}$ \\
\hline $\mathrm{P}($ Bequest $)$ Missing & $\begin{array}{r}-0.00811 \\
(0.0440)\end{array}$ & $\begin{array}{c}0.0252 \\
(0.0469)\end{array}$ & $\begin{array}{l}-0.0169 \\
(0.0251)\end{array}$ & $\begin{array}{l}-0.0150 \\
(0.0258)\end{array}$ & $\begin{array}{c}0.0285 \\
(0.0540)\end{array}$ & $\begin{array}{c}0.0249 \\
(0.0519)\end{array}$ & $\begin{array}{c}0.0626 \\
(0.0701)\end{array}$ & $\begin{array}{c}0.135^{*} \\
(0.0721)\end{array}$ \\
\hline $\mathrm{P}($ Live to 75$)>50 \%$ & $\begin{array}{c}0.0533 * * * \\
(0.0174)\end{array}$ & $\begin{array}{c}0.0258 \\
(0.0169)\end{array}$ & $\begin{array}{c}0.0186 \\
(0.0154)\end{array}$ & $\begin{array}{c}0.0134 \\
(0.0153)\end{array}$ & $\begin{array}{c}0.0289 \\
(0.0195)\end{array}$ & $\begin{array}{c}0.0166 \\
(0.0190)\end{array}$ & $\begin{array}{c}0.0717 * * * \\
(0.0257)\end{array}$ & $\begin{array}{c}0.0274 \\
(0.0247)\end{array}$ \\
\hline $\mathrm{P}($ Live to 75$)$ Miss & $\begin{array}{c}0.0530 \\
(0.0427)\end{array}$ & $\begin{array}{c}0.0387 \\
(0.0392)\end{array}$ & $\begin{array}{c}0.0480 \\
(0.0455)\end{array}$ & $\begin{array}{c}0.0470 \\
(0.0456)\end{array}$ & $\begin{array}{c}0.0246 \\
(0.0477)\end{array}$ & $\begin{array}{c}0.0275 \\
(0.0449)\end{array}$ & $\begin{array}{c}0.0166 \\
(0.0607)\end{array}$ & $\begin{array}{l}0.00594 \\
(0.0557)\end{array}$ \\
\hline Assets Quintile 2 & $\begin{array}{c}0.0345 \\
(0.0270)\end{array}$ & $\begin{array}{c}0.0288 \\
(0.0247)\end{array}$ & $\begin{array}{l}-0.0189 \\
(0.0341)\end{array}$ & $\begin{array}{r}-0.00292 \\
(0.0301)\end{array}$ & $\begin{array}{l}0.00970 \\
(0.0344)\end{array}$ & $\begin{array}{c}0.000526 \\
(0.0302)\end{array}$ & $\begin{array}{c}0.0334 \\
(0.0399)\end{array}$ & $\begin{array}{c}0.0149 \\
(0.0356)\end{array}$ \\
\hline Assets Quintile 3 & $\begin{array}{l}-0.0154 \\
(0.0271)\end{array}$ & $\begin{array}{r}-0.00928 \\
(0.0253)\end{array}$ & $\begin{array}{l}-0.0249 \\
(0.0343)\end{array}$ & $\begin{array}{l}0.00296 \\
(0.0330)\end{array}$ & $\begin{array}{l}-0.0174 \\
(0.0328)\end{array}$ & $\begin{array}{c}-0.0135 \\
(0.0300)\end{array}$ & $\begin{array}{c}-0.0387 \\
(0.0386)\end{array}$ & $\begin{array}{c}-0.0190 \\
(0.0360)\end{array}$ \\
\hline Assets Quintile 4 & $\begin{array}{l}-0.0316 \\
(0.0272)\end{array}$ & $\begin{array}{r}-0.00400 \\
(0.0255)\end{array}$ & $\begin{array}{l}-0.0504 * \\
(0.0297)\end{array}$ & $\begin{array}{l}-0.0303 \\
(0.0249)\end{array}$ & $\begin{array}{l}-0.0328 \\
(0.0329)\end{array}$ & $\begin{array}{r}-0.00677 \\
(0.0306)\end{array}$ & $\begin{array}{l}-0.0218 \\
(0.0401)\end{array}$ & $\begin{array}{c}0.000469 \\
(0.0371)\end{array}$ \\
\hline Assets Quintile 5 & $\begin{array}{c}-0.0208 \\
(0.0294)\end{array}$ & $\begin{array}{c}0.0329 \\
(0.0285)\end{array}$ & $\begin{array}{l}-0.0406 \\
(0.0289)\end{array}$ & $\begin{array}{c}-0.0290 \\
(0.0255)\end{array}$ & $\begin{array}{l}-0.0321 \\
(0.0337)\end{array}$ & $\begin{array}{c}0.00783 \\
(0.0333)\end{array}$ & $\begin{array}{l}-0.0239 \\
(0.0412)\end{array}$ & $\begin{array}{c}0.0172 \\
(0.0388)\end{array}$ \\
\hline Worked 35 Years & & $\begin{array}{c}-0.0404 * * \\
(0.0201)\end{array}$ & & $\begin{array}{c}-0.0666^{* * *} \\
(0.0217)\end{array}$ & & $\begin{array}{c}-0.0232 \\
(0.0234)\end{array}$ & & $\begin{array}{r}-0.0820^{* * *} \\
(0.0399)\end{array}$ \\
\hline Working & & $\begin{array}{c}0.145 * * * \\
(0.0314)\end{array}$ & & $\begin{array}{c}-0.0481 * * * \\
(0.0174)\end{array}$ & & $\begin{array}{c}0.0757 * * \\
(0.0371)\end{array}$ & & $\begin{array}{l}0.152 * * * \\
(0.0455)\end{array}$ \\
\hline $\mathrm{P}($ Work After 62$)>50 \%$ & & $\begin{array}{c}0.242 * * * \\
(0.0207)\end{array}$ & & $\begin{array}{l}0.00667 \\
(0.0561)\end{array}$ & & $\begin{array}{c}0.196 * * * \\
(0.0345)\end{array}$ & & $\begin{array}{l}0.289 * * * \\
(0.0273)\end{array}$ \\
\hline $\mathrm{P}$ (Work After 62) Missing & & $\begin{array}{c}0.0391 \\
(0.0354)\end{array}$ & & $\begin{array}{r}-0.0140 \\
(0.0291)\end{array}$ & & $\begin{array}{c}0.0290 \\
(0.0334)\end{array}$ & & $\begin{array}{c}0.0120 \\
(0.0514)\end{array}$ \\
\hline $\begin{array}{l}\text { Mean of Dep. Var. } \\
\text { Sample } \\
\text { Early Claim Def'n } \\
\text { Observations }\end{array}$ & \multicolumn{2}{|c|}{$\begin{array}{c}0.2391 \\
\text { All } \\
62 \\
2,702 \\
\end{array}$} & \multicolumn{2}{|c|}{$\begin{array}{l}\quad(0.0291) \\
0.0526 \\
\text { ired Before } 62 \\
62 \\
817\end{array}$} & \multicolumn{2}{|c|}{\begin{tabular}{|c|}
0.1357 \\
Not Working at Claim \\
62 or Last Worked \\
1,319
\end{tabular}} & \multicolumn{2}{|c|}{$\begin{array}{c}0.2760 \\
\text { Males } \\
62 \\
1,413 \\
\end{array}$} \\
\hline
\end{tabular}

Coefficients are average marginal effects from probit model. Standard errors (clustered by household) in parentheses.

$* * * \mathrm{p}<0.01, * * \mathrm{p}<0.05, * \mathrm{p}<0.1$ 
Table 6: Determinants of Delay Length

\begin{tabular}{|c|c|c|c|c|c|c|c|c|}
\hline & $(1)$ & $(2)$ & (3) & $(4)$ & $(5)$ & $(6)$ & $(7)$ & $(8)$ \\
\hline Married Female & $\begin{array}{c}-5.108 * * * \\
(0.758)\end{array}$ & $\begin{array}{c}-2.376^{* * *} \\
(0.849)\end{array}$ & $\begin{array}{c}3.896 * * * \\
(0.864)\end{array}$ & $\begin{array}{c}0.799 \\
(1.057)\end{array}$ & $\begin{array}{c}3.083 * * * \\
(0.638)\end{array}$ & $\begin{array}{c}0.849 \\
(0.724)\end{array}$ & & \\
\hline Single Male & $\begin{array}{c}1.302 \\
(1.703)\end{array}$ & $\begin{array}{c}0.519 \\
(1.498)\end{array}$ & $\begin{array}{c}3.058 \\
(2.384)\end{array}$ & $\begin{array}{c}2.387 \\
(2.307)\end{array}$ & $\begin{array}{c}2.149 \\
(1.536)\end{array}$ & $\begin{array}{c}1.627 \\
(1.510)\end{array}$ & $\begin{array}{c}1.458 \\
(1.736)\end{array}$ & $\begin{array}{c}0.450 \\
(1.509)\end{array}$ \\
\hline Single Female & $\begin{array}{c}0.826 \\
(1.309)\end{array}$ & $\begin{array}{c}-0.255 \\
(1.253)\end{array}$ & $\begin{array}{c}2.314 \\
(1.568)\end{array}$ & $\begin{array}{c}0.267 \\
(1.670)\end{array}$ & $\begin{array}{c}1.080 \\
(0.915)\end{array}$ & $\begin{array}{l}0.0147 \\
(0.917)\end{array}$ & & \\
\hline African American & $\begin{array}{c}-0.291 \\
(1.281)\end{array}$ & $\begin{array}{c}1.039 \\
(1.187)\end{array}$ & $\begin{array}{c}1.278 \\
(1.694)\end{array}$ & $\begin{array}{c}1.662 \\
(1.663)\end{array}$ & $\begin{array}{c}2.340 * * \\
(1.123)\end{array}$ & $\begin{array}{l}2.273^{* *} \\
(1.114)\end{array}$ & $\begin{array}{c}0.390 \\
(1.985)\end{array}$ & $\begin{array}{c}1.472 \\
(1.762)\end{array}$ \\
\hline Other Race & $\begin{array}{c}1.302 \\
(2.150)\end{array}$ & $\begin{array}{l}3.581 * \\
(1.929)\end{array}$ & $\begin{array}{c}1.223 \\
(3.116)\end{array}$ & $\begin{array}{c}1.068 \\
(3.023)\end{array}$ & $\begin{array}{c}2.707 \\
(2.164)\end{array}$ & $\begin{array}{c}2.283 \\
(2.129)\end{array}$ & $\begin{array}{c}1.084 \\
(2.763)\end{array}$ & $\begin{array}{c}3.351 \\
(2.439)\end{array}$ \\
\hline Some College & $\begin{array}{c}5.616^{* * *} \\
(0.848)\end{array}$ & $\begin{array}{c}3.861 * * * \\
(0.766)\end{array}$ & $\begin{array}{l}1.944 * \\
(1.032)\end{array}$ & $\begin{array}{l}2.171 * * \\
(1.021)\end{array}$ & $\begin{array}{c}1.666^{* *} \\
(0.701)\end{array}$ & $\begin{array}{l}1.736^{* *} \\
(0.695)\end{array}$ & $\begin{array}{c}5.923 * * * \\
(1.173)\end{array}$ & $\begin{array}{c}4.500 * * * \\
(1.053)\end{array}$ \\
\hline Interest Rate & $\begin{array}{c}-0.194 \\
(0.589)\end{array}$ & $\begin{array}{l}-0.0619 \\
(0.549)\end{array}$ & $\begin{array}{c}-0.160 \\
(0.666)\end{array}$ & $\begin{array}{l}-0.160 \\
(0.716)\end{array}$ & $\begin{array}{c}-0.00314 \\
(0.451)\end{array}$ & $\begin{array}{c}-0.108 \\
(0.468)\end{array}$ & $\begin{array}{c}0.122 \\
(0.894)\end{array}$ & $\begin{array}{c}0.123 \\
(0.782)\end{array}$ \\
\hline Unemployment Rate & $\begin{array}{c}0.398 \\
(0.517)\end{array}$ & $\begin{array}{c}0.420 \\
(0.475)\end{array}$ & $\begin{array}{l}-0.821 \\
(0.616)\end{array}$ & $\begin{array}{c}-0.935 \\
(0.641)\end{array}$ & $\begin{array}{l}-0.632 \\
(0.411)\end{array}$ & $\begin{array}{l}-0.741 * \\
(0.413)\end{array}$ & $\begin{array}{l}1.345^{*} \\
(0.767)\end{array}$ & $\begin{array}{l}1.214^{*} \\
(0.650)\end{array}$ \\
\hline Long Planning Horizon & $\begin{array}{c}1.004 \\
(0.785)\end{array}$ & $\begin{array}{c}1.013 \\
(0.704)\end{array}$ & $\begin{array}{c}-0.252 \\
(0.844)\end{array}$ & $\begin{array}{c}-0.277 \\
(0.838)\end{array}$ & $\begin{array}{c}-0.104 \\
(0.595)\end{array}$ & $\begin{array}{c}-0.197 \\
(0.590)\end{array}$ & $\begin{array}{c}1.078 \\
(1.132)\end{array}$ & $\begin{array}{c}1.225 \\
(0.991)\end{array}$ \\
\hline Planning Horizon Missing & $\begin{array}{c}-0.241 \\
(2.940)\end{array}$ & $\begin{array}{c}1.041 \\
(2.693)\end{array}$ & $\begin{array}{c}-1.892 \\
(3.313)\end{array}$ & $\begin{array}{l}-2.440 \\
(3.242)\end{array}$ & $\begin{array}{c}1.343 \\
(2.044)\end{array}$ & $\begin{array}{c}0.644 \\
(1.970)\end{array}$ & $\begin{array}{c}-0.808 \\
(3.424)\end{array}$ & $\begin{array}{c}0.924 \\
(3.090)\end{array}$ \\
\hline $\mathrm{P}($ Bequest $) \geq 50 \%$ & $\begin{array}{c}0.135 \\
(0.837)\end{array}$ & $\begin{array}{c}-0.474 \\
(0.753)\end{array}$ & $\begin{array}{c}0.628 \\
(0.895)\end{array}$ & $\begin{array}{c}0.652 \\
(0.886)\end{array}$ & $\begin{array}{l}0.0842 \\
(0.584)\end{array}$ & $\begin{array}{c}0.0848 \\
(0.590)\end{array}$ & $\begin{array}{c}-0.00343 \\
(1.202)\end{array}$ & $\begin{array}{c}-0.244 \\
(1.058)\end{array}$ \\
\hline $\mathrm{P}$ (Bequest) Missing & $\begin{array}{c}0.169 \\
(2.164)\end{array}$ & $\begin{array}{c}1.413 \\
(2.023)\end{array}$ & $\begin{array}{c}-0.427 \\
(2.556)\end{array}$ & $\begin{array}{c}-0.727 \\
(2.570)\end{array}$ & $\begin{array}{c}0.126 \\
(1.199)\end{array}$ & $\begin{array}{c}0.352 \\
(1.298)\end{array}$ & $\begin{array}{c}2.819 \\
(2.961)\end{array}$ & $\begin{array}{l}5.403 * * \\
(2.661)\end{array}$ \\
\hline $\mathrm{P}($ Live to 75$)>50 \%$ & $\begin{array}{l}1.983^{* *} \\
(0.807)\end{array}$ & $\begin{array}{c}0.429 \\
(0.739)\end{array}$ & $\begin{array}{c}0.140 \\
(0.955)\end{array}$ & $\begin{array}{l}-0.125 \\
(0.941)\end{array}$ & $\begin{array}{c}0.162 \\
(0.628)\end{array}$ & $\begin{array}{l}0.0494 \\
(0.617)\end{array}$ & $\begin{array}{c}2.634 * * \\
(1.184)\end{array}$ & $\begin{array}{l}-0.0441 \\
(1.044)\end{array}$ \\
\hline $\mathrm{P}($ Live to 75$)$ Missing & $\begin{array}{c}2.050 \\
(1.984)\end{array}$ & $\begin{array}{c}1.035 \\
(1.805)\end{array}$ & $\begin{array}{c}2.690 \\
(2.732)\end{array}$ & $\begin{array}{c}2.242 \\
(2.701)\end{array}$ & $\begin{array}{c}-0.593 \\
(1.152)\end{array}$ & $\begin{array}{c}-0.551 \\
(1.215)\end{array}$ & $\begin{array}{l}-0.150 \\
(2.818)\end{array}$ & $\begin{array}{c}-1.941 \\
(2.525)\end{array}$ \\
\hline Assets Quintile 2 & $\begin{array}{c}1.454 \\
(1.228)\end{array}$ & $\begin{array}{c}1.517 \\
(1.158)\end{array}$ & $\begin{array}{c}-2.080 \\
(1.700)\end{array}$ & $\begin{array}{l}-1.739 \\
(1.649)\end{array}$ & $\begin{array}{c}-0.463 \\
(0.954)\end{array}$ & $\begin{array}{l}-0.0476 \\
(0.934)\end{array}$ & $\begin{array}{c}2.206 \\
(1.831)\end{array}$ & $\begin{array}{c}1.462 \\
(1.699)\end{array}$ \\
\hline Assets Quintile 3 & $\begin{array}{c}-0.966 \\
(1.210)\end{array}$ & $\begin{array}{c}-0.381 \\
(1.162)\end{array}$ & $\begin{array}{c}-1.992 \\
(1.731)\end{array}$ & $\begin{array}{c}-0.874 \\
(1.636)\end{array}$ & $\begin{array}{l}-0.550 \\
(0.973)\end{array}$ & $\begin{array}{c}0.142 \\
(0.962)\end{array}$ & $\begin{array}{l}-1.851 \\
(1.778)\end{array}$ & $\begin{array}{c}-0.278 \\
(1.661)\end{array}$ \\
\hline Assets Quintile 4 & $\begin{array}{l}-2.331^{*} \\
(1.308)\end{array}$ & $\begin{array}{c}-0.121 \\
(1.234)\end{array}$ & $\begin{array}{c}-3.991 * * \\
(1.652)\end{array}$ & $\begin{array}{c}-3.377 * * \\
(1.572)\end{array}$ & $\begin{array}{c}-0.422 \\
(0.979)\end{array}$ & $\begin{array}{l}-0.0701 \\
(0.982)\end{array}$ & $\begin{array}{c}-0.989 \\
(1.899)\end{array}$ & $\begin{array}{c}0.876 \\
(1.747)\end{array}$ \\
\hline Assets Quintile 5 & $\begin{array}{l}-2.598 * \\
(1.434)\end{array}$ & $\begin{array}{c}1.099 \\
(1.329)\end{array}$ & $\begin{array}{c}-3.857 * * \\
(1.623)\end{array}$ & $\begin{array}{c}-3.551^{* *} \\
(1.564)\end{array}$ & $\begin{array}{c}-0.454 \\
(0.937)\end{array}$ & $\begin{array}{c}-0.397 \\
(0.940)\end{array}$ & $\begin{array}{l}-2.469 \\
(1.995)\end{array}$ & $\begin{array}{c}0.594 \\
(1.837)\end{array}$ \\
\hline Worked 35 Years & & $\begin{array}{c}-2.341 * * * \\
(0.875)\end{array}$ & & $\begin{array}{c}-4.639 * * * \\
(1.091)\end{array}$ & & $\begin{array}{c}-2.987 * * * \\
(0.747)\end{array}$ & & $\begin{array}{l}-3.115^{*} \\
(1.718)\end{array}$ \\
\hline Working & & $\begin{array}{c}9.827 * * * \\
(1.378)\end{array}$ & & $\begin{array}{c}-1.808 \\
(1.434)\end{array}$ & & $\begin{array}{c}-2.580 * * \\
(1.185)\end{array}$ & & $\begin{array}{c}11.72 * * * \\
(2.084)\end{array}$ \\
\hline $\mathrm{P}($ Work After 62$)>50 \%$ & & $\begin{array}{c}14.36^{* * *} \\
(0.864)\end{array}$ & & $\begin{array}{l}-2.303 \\
(1.520)\end{array}$ & & $\begin{array}{c}-0.444 \\
(0.685)\end{array}$ & & $\begin{array}{c}16.41 * * * \\
(1.115)\end{array}$ \\
\hline $\mathrm{P}($ Work After 62) Missing & & $\begin{array}{l}3.483 * * \\
(1.426)\end{array}$ & & $\begin{array}{c}0.760 \\
(1.454)\end{array}$ & & $\begin{array}{c}-0.538 \\
(1.227) \\
\end{array}$ & & $\begin{array}{c}2.771 \\
(2.184) \\
\end{array}$ \\
\hline $\begin{array}{l}\text { Mean of Dep. Var. } \\
\text { Sample } \\
\text { Early Claim Def'n } \\
\text { Observations }\end{array}$ & \multicolumn{2}{|c|}{$\begin{array}{c}16.4141 \\
\text { All } \\
62 \\
2,702 \\
\end{array}$} & \multicolumn{2}{|c|}{$\begin{array}{c}5.4345 \\
\text { Retired Before } 62 \\
62 \\
817 \\
\end{array}$} & \multicolumn{2}{|c|}{\begin{tabular}{|c|}
4.0972 \\
Not Working at Claim \\
62 or Last Worked \\
1,319 \\
\end{tabular}} & \multicolumn{2}{|c|}{$\begin{array}{c}18.5018 \\
\text { Males } \\
62 \\
1,413 \\
\end{array}$} \\
\hline
\end{tabular}

Tobit regressions, with dependent variable censored at zero. Constant terms not reported. Standard errors (clustered by household) in parentheses. $* * * \mathrm{p}<0.01, * * \mathrm{p}<0.05, * \mathrm{p}<0.1$ 